\title{
Surface ozone at the Caucasian site Kislovodsk High Mountain Station and the Swiss Alpine site Jungfraujoch: data analysis and trends (1990-2006)
}

\author{
O. A. Tarasova ${ }^{1,{ }^{*}}$, I. A. Senik ${ }^{2}$, M. G. Sosonkin ${ }^{3}$, J. Cui ${ }^{4}$, J. Staehelin ${ }^{4}$, and A. S. H. Prévôt ${ }^{5}$ \\ ${ }^{1}$ Max-Planck Institute for Chemistry, Mainz, Germany \\ ${ }^{2}$ Obukhov Institute of Atmosphere Physics RAS, Moscow, Russia \\ ${ }^{3}$ International Center for Astronomical, Medical and Ecological Research NAS, Kiev, Ukraine \\ ${ }^{4}$ Institute for Atmospheric and Climate Science, Swiss Federal Institute of Technology Zürich, Switzerland \\ ${ }^{5}$ Paul Scherrer Institute, Villigen, Switzerland \\ *currently at: WMO, Atmospheric Environment Research Department, Switzerland
}

Received: 15 October 2008 - Published in Atmos. Chem. Phys. Discuss.: 13 January 2009

Revised: 3 June 2009 - Accepted: 9 June 2009 - Published: 23 June 2009

\begin{abstract}
Long-term ozone measurements of two background mountain sites, namely the Kislovodsk High Mountain Station in Caucasus, Russia (KHMS, $43.70^{\circ} \mathrm{N}, 42.70^{\circ} \mathrm{E}$, $2070 \mathrm{~m}$ a.s.l.) and the Jungfraujoch in Switzerland (JFJ, $46.55^{\circ} \mathrm{N}, 7.98^{\circ} \mathrm{E}, 3580 \mathrm{~m}$ a.s.l.) are compared. Despite of more than $1.5 \mathrm{~km}$ altitude difference ozone mixing ratios are comparable at JFJ an KHMS in the beginning of measurements (1990-1993) while the annually averaged levels at JFJ are around $15 \mathrm{ppb}$ higher than the ones at KHMS for the most recent years (1997-2006). The seasonal cycle of the surface ozone mixing ratios is characterized by a double spring-summer maximum at both sites with a spring one being more pronounced for the air masses with the longest contact with the upper free troposphere and stratosphere. Ozone mixing ratio increased at JFJ but decreased at KHMS for the period 1990-2006. Trends are more pronounced for the $1990 \mathrm{~s}(+0.73 \pm 0.20 \mathrm{ppb} / \mathrm{year}$ at JFJ and $-0.91 \pm 0.17 \mathrm{ppb} / \mathrm{year}$ at KHMS for the period 1991-2001) in comparison with the later years $(+0.04 \pm 0.21 \mathrm{ppb} /$ year at JFJ and $-0.37 \pm 0.14 \mathrm{ppb} /$ year at KHMS for the period 1997 2006). Trends show a distinct seasonality, which is different for the different periods. To investigate possible reasons for this remarkable trends difference 3-D trajectories using LAGRANTO trajectory model are used. Effects of horizontal and vertical transport on ozone trends are considered. No substantial systematic changes in the transport patterns were
\end{abstract}

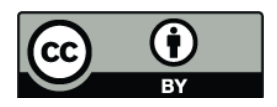

Correspondence to: O. A. Tarasova (tarasova@mpch-mainz.mpg.de) detected which could lead to strong changes in the trend magnitude between 1991-2001 and 1997-2006. The geographical position of the sites relative to the main topographic features and emission sources as well as distance from the coast are interpreted to be among the main reasons for the opposite surface ozone trends. During the 90 s the JFJ trend reflects increase of the ozone in the upper free troposphere/lower stratosphere, while KHMS is not sensitive to this change or even showing the opposite tendency. The analysis provided evidence for a stronger influence of processes in the lower troposphere, in particular the dramatic emission decrease in the earlier 1990s in former USSR and emissions regulations in Western Europe on the surface ozone trend at KHMS.

\section{Introduction}

Ozone plays a crucial role in tropospheric chemistry as it is the most important compound of photooxidant air pollution, it determines the oxidation capacity as the main precursor for $\mathrm{OH}$ radical and it is a significant greenhouse gas (IPCC, 2007). Surface ozone concentration is highly variable both in space and time, on long and short scales. Trend determination of tropospheric/surface ozone is often a difficult task because an accuracy of ozone gas analyzers is sometimes smaller than observed long-term changes (Virgazan, 2004; Oltmans et al., 2006; Brönnimann et al., 2002; TOR2 report, 2003; Jaffe and Ray, 2007). Nevertheless it is well established that surface ozone concentration at unpolluted sites in Europe increased by more than a factor of two

Published by Copernicus Publications on behalf of the European Geosciences Union. 
between the 1950s and the early 1990s (e.g. Staehelin et al., 1994), most probably due to large increase in ozone precursor emissions. Since the late 1980s measures are undertaken to reduce ozone precursor emissions in western European countries. During the 1990s anthropogenic $\mathrm{NO}_{\mathrm{x}}$ emissions deceased in Germany and Switzerland by more than $30 \%$, the VOC emissions decrease was even larger (EMEP, 2004). Dramatic emissions decrease most probably also took place in the New Independent State due to the economic crisis following the end of the Soviet Union (USSR) in the beginning of the 1990s.

Ozone concentration in ambient air does not show a simple linear response to the emission changes of the ozone precursors (nitrogen oxides $\left(\mathrm{NO}_{\mathrm{x}}: \mathrm{NO}+\mathrm{NO}_{2}\right)$ and volatile organic compounds - VOCs). It has been shown, that peak ozone concentrations over Europe decreased at some sites since the early 1990s (TOR-2, 2003; Jonson et al., 2006 and references therein), but the decrease in high ozone concentrations was rather small in the planetary boundary layer (PBL) of the Swiss plateau (Ordóñez et al., 2005). At the same time background ozone concentration over Europe substantially increased during the 1990s. Simmonds et al. (2004) showed that background ozone in the clean oceanic sector measured at Mace Head, Ireland increased by about $8 \mathrm{ppb}$ for the period 1987-2003 (more in winter than in summer). In the recent years the stabilization of the trend is observed at the inflow of European continent (Derwent et al., 2007), while surface ozone concentration continue to increase at the inflow of the American western coast (Parrish et al., 2009). Substantial increases of the surface ozone concentrations were documented for European high alpine sites (Jungfraujoch, Zugspitze, Sonnblick) by Brönnimann et al. (2002) and Ordóñez et al. (2007). Thouret et al. (2006) and Zbinden et al. (2006) reported from regular aircraft measurements MOZAIC an overall increase in ozone concentration in the upper troposphere and the lower stratosphere of about $1 \% / \mathrm{yr}$ for 1994-2003 (extending over Europe, North Atlantic and eastern US) and Jaffe and Ray (2007) documented increasing ozone levels for most of the elevated locations in the eastern rural USA regions for the 90s.

Several reasons can cause long-term ozone changes at a particular receptor site, including the response on the emission changes (both natural and anthropogenic), changes of the stratospheric contribution and changes of the transport patterns (both of horizontal and vertical direction). These processes can affect the trends differently in the individual seasons. An ozone precursor increase is expected 1) to increase ozone concentration by photochemical formation downwind of emission sources in the warm season, 2) to decrease ozone in winter due to the effect of ozone titration by NO. Stratospheric ozone contribution is expected to be the most important for spring trends due to stratospheric ozone maximum in this season; hence an increase of the stratospheric flux is expected to yield the most positive trend in spring, if the intensity of STE changes uniformly for all the seasons. Changes in the transport patterns can cause trends of both signs depending on the spatial ozone distribution and precursors' concentration changes in the areas of air masses origin.

At present, the reasons of the background ozone growth in Europe are still under debate. Jonson et al. (2006) used a regional model to show that decreasing European $\mathrm{NO}_{\mathrm{x}}$ emissions can explain only part of the observed increase in winter ozone at polluted sites (due to decrease in titration) and the decrease in the high summer ozone episodes was less than expected from the precursor emission decrease. Therefore it was suggested that changes in ozone concentration advected to Europe could have partially compensated the expected decrease. This was corroborated by Andreani-Aksoyoglu et al. (2008) for model analysis of Swiss ozone trends. The trends observed at high mountain sites are not reproduced by global models even when considering the dramatic increase of South-East Asia emissions since 1990 and estimates obtained with state of art global numerical simulations (e.g. Auvray and Bey, 2005; Stevenson et al., 2006; Koumoutsaris et al., 2008) can only partially explain ozone winter increase at high alpine sites. Ordóñez et al. (2007) suggested that an increased transport of ozone from the stratosphere could be responsible for a substantial part of the increase in the background ozone found at European mountain sites. A substantial contribution of stratospheric ozone to interannual variability of northern extratropical tropospheric ozone was also found by Terao et al. (2008).

In this study we compare long-term ozone measurements at Kislovodsk High Mountain Station (KHMS, 2070 m a.s.l.) located at the eastern border of Europe at the Caucasus Mountains, and those of the mountainous site Jungfraujoch (JFJ, 3580 m a.s.1.) located in the Swiss Alps with the aim to understand the reason of the different ozone changes at two background stations. At KHMS negative ozone trends have been documented earlier (Senik et al., 2001, 2005; Tarasova et al., 2003) and we publish here the ozone measurements of the last years. Unlike the most reporting sites KHMS is situated very deep inside the continent. It has the highest European mountain peak to the south and the main Caucasus mountain ridge in the latitudinal direction. Air advection to the site is impacted to a substantial degree by Arabian, Sahara and Siberia anticyclones causing strong large-scale vertical motions in the Caucasus region (Liu et al., 2009). In this paper we use a trajectory analysis as a tool to separate air masses of different origin and to study the contributions of the different source regions to the observed variability of the surface ozone mixing ratio at the two mountain sites. 


\section{Measurements and methods}

\subsection{Ozone measurements}

Continuous measurements of the surface ozone concentration used in this paper are performed at Kislovodsk High Mountain Station (KHMS) $\left(43.70^{\circ} \mathrm{N}, 42.70^{\circ} \mathrm{E}\right.$, $2070 \mathrm{~m}$ a.s.l., Caucasus mountain region) and at Jungfraujoch station (JFJ) $\left(46.55^{\circ} \mathrm{N}, 7.98^{\circ} \mathrm{E}, 3580 \mathrm{~m}\right.$ a.s.l., the Alps). The map showing the positions of the sites is presented in Fig. 1. In this paper ozone concentration time series from 1990 to 2006 with hourly resolutions are used for both stations. We report ozone levels in terms of mixing ratios (in $\mathrm{ppb).}$

KHMS is situated on the mountain plateau $18 \mathrm{~km}$ to the south of the resort town Kislovodsk and $48 \mathrm{~km}$ to the north of the highest top of the Caucasus, Elbrus mountain (5642 $\mathrm{m}$ a.s.l.). The site is situated on the plateau at the northern slope of the side ridge of the main Caucasus mountain crest. The main Caucasus Ridge is located to the south of the site nearly along the latitude line (W-NW to E-SE), and it disturbs the main northern midlatitudes airflow (Westerlies) much less in comparison with the Alps in Europe. A system of anticyclones in the region (Arabian and Sahara) impacts vertical and horizontal air transport in particular in summer (Liu et al., 2009). A more detailed station description can be found in Tarasova et al. (2003 and references therein) and Senik et al. (2005). The ozone instrument used at KHMS (DASIBI model 1008-AH nr. 4565) is based on UV photometry and it is regularly calibrated. In earlier years the calibration was performed against the transfer standard of Max-Planck Institute for Chemistry in Mainz (Germany) (DASIBI-1008RS nr. 6394). Since 2003 the calibrations are done directly and indirectly. The direct calibration is performed by a comparison with a secondary standard instrument (Env. O3-41M, nr. 1298) of the Obukhov Institute of Atmospheric Physics (Moscow, Russia) calibrated in Stockholm against primary standard SPR nr. 11. Indirect calibrations (pre-calibration) are carried out using the transfer standard DASIBI-1008RS nr. 6394 in accordance with a methodology described in Klausen et al. (2003) for the subsequent comparison of the working instrument DASIBI 1008AH nr. 4565 (at KHMS) with the transfer (secondary) standard device Env O3-41M nr. 1298 (in Moscow). Calibrations are carried out in accordance with the international standard (ISO 13964). The accuracy is expected to be $1-2 \mathrm{ppb}$. Measurements at the station are continuously performed since 1989. The dataset has some gaps due to instrument transportation to calibration centers, instrument service or critical weather conditions (long dense fog).

JFJ is situated at the north-western slope of the Swiss Alps (Fig. 1) and resides most of time in the free troposphere, particularly in winter and often in spring and autumn (Zellweger et al., 2003; Henne et al., 2005; Baltensperger et al., 1997). Detailed description of the site can be found in sev-

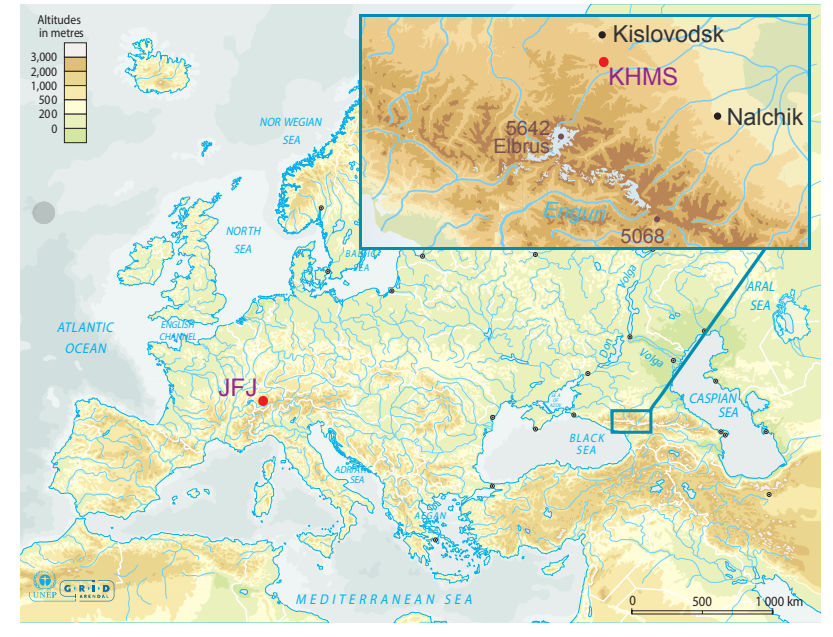

Fig. 1. Position of the ozone measurement stations which data are used in the paper. The Caucasus region is presented in more details in the upper corner. The map is compiled from two maps of UNEP/GRID-Arendal Maps and Graphics Library (UNEP/GRID-Arendal. The Caucasus ecoregion, topographic map. UNEP/GRID-Arendal Maps and Graphics Library. 2008. Available at: http://maps.grida.no/go/graphic/ the-caucasus-ecoregion-topographic-map. Accessed June 12, 2008 and UNEP/GRID-Arendal. How the comb-jelly (Mnemiopsis leidyi) is spreading through European seas (invasive species). UNEP/GRID-Arendal Maps and Graphics Library. 2007. Available at: http://maps.grida.no/library/files/storage/ 06-bio-axesoceans.png. Accessed June 12, 2008).

eral publications (EMPA, 2000; Schuepbach et al., 2001; Zanis et al., 2007). $\mathrm{O}_{3}$ concentration is continuously measured within the Swiss National Air Pollution Monitoring Network (NABEL) that is run by Empa (Swiss Federal Laboratories for Material Testing and Research, Dübendorf) in joint collaboration with the Swiss Federal Office for the Environment (FOEN, Bern) using a commercially available instrument (Thermo Environmental Instruments, Model 49C, UV absorption). The instrument is regularly compared to a transfer standard (TEI 49C PS) which is traced back to a NIST standard reference photometer. The detection limit is $0.5 \mathrm{ppb}$, the measurement uncertainty is determined to be $\pm 2 \%(1 \sigma)$, neglecting the uncertainty of the absorption coefficient. Zanis et al. (1999) and Brönnimann et al. (2000) provided evidence for data quality problem of JFJ ozone measurements before 1991 and therefore we excluded these data from our analyses with backward trajectories.

Statistical characteristics of the ozone datasets and distribution functions are based on the hourly mean data. All ozone subsets related to the impact of the air transport are based on $5 \mathrm{~h}$ running averages centered at the time of the air masses arrival to the respective station. This procedure does not impact the estimates of trends and characteristics of the seasonal cycles, but improves the data statistics in the cases of data gaps exactly at the time of air masses arrival. 


\subsection{Backward trajectories and data filtering}

To attribute ozone concentration variability to the origin and the history of air masses arriving to the receptor point we use 3-D trajectories calculated with the help of trajectory tool LAGRANTO (Wernli and Davies, 1997). The trajectories are based on the three-dimensional wind fields of the recent 40-years reanalysis data set (ERA-40) of the European Centre for Medium Range Weather Forecast; for the period after ERA-40 (i.e. after August 2002) operational ECMWF analysis is used instead. Trajectories are calculated for 10 days back in time and have $6 \mathrm{~h}$ temporal resolution. The altitudes of the sites are taken into account by choosing the appropriate arrival level, i.e. $650 \mathrm{hPa}$ for JFJ (level 5 of the trajectory model) and $750 \mathrm{hPa}$ for KHMS (level 3 of the trajectory model). The selected levels correspond to the average pressure levels observed at the stations. We assume adiabatic transport (along isobars). Selected trajectory model levels corresponds to the physical altitude of the stations, which is (particularly for JFJ) higher than the model altitude of the planetary boundary layer height at the receptor site. The "surface" level of the trajectory model is at $850 \mathrm{hPa}$ for both locations due to the poor representation of the topography in the trajectory (and in re-analysis) model. The receptor height of trajectory analysis for JFJ was selected to represent free tropospheric air since several studies provided evidence (Zellweger et al., 2003; Baltensperger et al., 1997) that the air composition at JFJ is often more typical for the free troposphere than the polluted European planetary boundary layer.

Trajectories are used to trace the origin of the air mass arriving to the station both in vertical and horizontal direction. For this aim the diagnostic parameters potential vorticity (PV), altitude along the trajectory and PBL height from meteorological re-analysis data are used to discriminate different vertical source areas. Air parcels coordinates along the trajectory are used to study the horizontal transport patterns.

Several filters are applied to select the air masses being in contact with the free troposphere and the stratosphere (in the text referred to as FT/ST cases), namely:

- the altitude of the air parcel along the trajectory at least once exceeds $400 \mathrm{hPa}$ level;

- the altitude of the air parcel along the trajectory at least once exceeds $500 \mathrm{hPa}$ level and PV value exceeds 1.3 PVU;

- the altitude of the air parcel along the trajectory at least once exceeds $500 \mathrm{hPa}$ level and PV value exceeds 1.6 PVU;

- the altitude of the air parcel along the trajectory at least once exceeds $500 \mathrm{hPa}$ level and PV value exceeds 2 PVU.
Note, that altitude and PV criteria need to be fulfilled simultaneously at some point of the trajectory. The use of PV value alone as an indicator of the free tropospheric/stratospheric air is not sufficient due to complex topography of the studied locations, which can create some local flows with high vorticity. The trajectory is considered as belonging to the respective subset independently of the time when the criteria are satisfied. Hence the selected classes are non-uniform due to air masses chemical processing and turbulent mixing on the way to the receptor point. If contact with the stratosphere occurred 10 days back prior to the air parcel arrival at the site, the probability to observe enhanced concentration is much lower than in the cases of the direct stratospheric intrusion at the receptor point. We did not perform time filtering in addition to the criteria described above to keep the statistical representativeness of the subsets.

Two filters are applied to trace the air masses which were in contact with the PBL:

- the altitude of the air parcel along the trajectory is at least once lower than the PBL height east of $10 \mathrm{~W}$ (over European continent);

- the altitude of the air parcel along the trajectory is lower than the PBL height at least during two days of the last 5 days before arriving at the site (without geographical limitation).

We note that the selected trajectory approach has some limitations to distinguish the air masses of different histories. A particular set of criteria to study the impact of the air advection from the upper troposphere/low stratosphere supposes the inclusion of the stricter criteria into the weaker ones. The weakest criterion is " $p<400 \mathrm{hPa}$ " which mostly corresponds to the transport in the upper troposphere. Inclusion of PV criteria can show the different degree of the stratospheric air dissipation in the troposphere. Level of PV > 2 PVU corresponds to the cross-tropopause transport. However, the fulfillment of a particular criterion along the trajectory describes only one particular property of the air mass because it might start in the stratosphere and spend several hours in the PBL over the continent before arrival at the receptor site. This implies that even when filtering the datasets according to one particular criterion the air parcel is expected to reflect the overall effect of processes including different properties from the different parts of the air mass history. However, the trajectory analysis is believed to be a useful method to distinguish the influences of the different source areas of ozone/precursors on the surface ozone trend at a particular location.

The monthly mean ozone concentrations are calculated for the individual subsets. The filtered monthly means are used for the calculation of the averaged seasonal cycles and for the annual and seasonal trend estimates. Because the concentration changes are not uniform in time we consider and compare two different time periods, namely 1991-2001 
with large concentration changes at both sites and 1997-2006 when ozone changes were much smaller. Both considered periods cover at least 10 years which is expected to minimize large effects of the years at the beginning and at the end of the series on trend estimates. Moreover, an earlier study investigating homogeneities and trends of the ozone record at JFJ from 1988 to 1996 revealed a shift discontinuity in 1991 (Zanis et al., 1999). There are also a lot of missing data at both sites in 1990, hence we avoided using these data as an initial point of the trend estimates.

To analyze the impact of horizontal advection on the observed variations of the surface ozone concentration the trajectories arriving to the sites are classified. Cluster analysis is performed for the trajectories of total length (10 days back) and for the whole period (1990-2006) so that the main transport directions are the same for the different considered periods (1991-2001 and 1997-2006). The classification is done by means of k-mean clustering of the horizontal air parcel coordinates (latitude and longitude) which are the most important variables (a description of the algorithm can be found for example in Cape et al., 2000 and in Tarasova et al., 2007 and references therein). The average vertical transport usually occurs much slower than horizontal advecton which makes the vertical coordinate less variable and hence less efficient for trajectory's bunches discrimination. The same number of clusters (namely 7) is selected for both sites.

One can argue that transport patterns may have changed from the period 1991-2001 to the period 1997-2006, and therefore classification should have been performed for the selected periods separately. However, the selected procedure can take such changes into account by means of the interannually changing frequency, while classification of the separate periods makes the comparison of the obtained clusters more difficult.

\section{Results}

\subsection{Statistical characteristics and distribution functions}

Figure 2 shows ozone monthly mean mixing ratios with standard deviation at JFJ and KHMS, calculated based on the hourly mean data. In the beginning of the dataset (19901993) the measured mixing ratios at both elevated sites are quite close to each other. In 1991 the lowest annual mixing ratio is observed at JFJ for the whole 16-years period while the highest one is observed at KHMS. Between 1991 and 1996 a strong increase of the surface ozone mixing ratio is observed at JFJ and a strong decrease is found at KHMS, whereas in the later period ozone levels at both sites stabilized. The decrease at KHMS for the 90-s was first documented by Senik and Elansky (2001), while the more recent data were not published yet. Average rates of change for the whole period 1990-2006 are shown in Table 1 together with the other statistical characteristics of the datasets
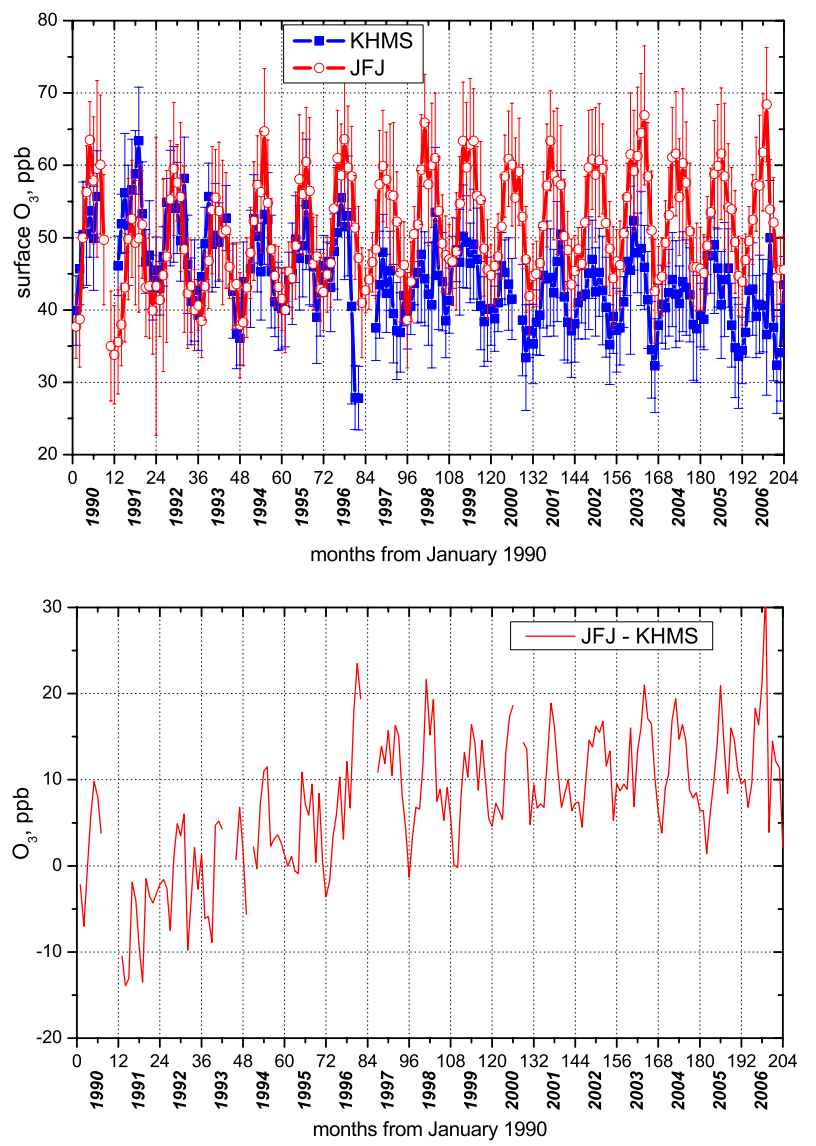

Fig. 2. (a) Monthly mean surface ozone mixing ratios at KHMS and JFJ, determined from hourly mean values. Plain squares and blue line corresponds to KHMS observations, open circles and red line corresponds to JFJ observations. Error bars show one standard deviation of the monthly mean determination. (b) Difference of the monthly mean ozone mixing ratios at JFJ and KHMS. Note an extreme difference in summer of 2006.

based on the hourly mean mixing ratios. Due to anomalous ozone variations in 2005 and 2006, statistics for these particular years is presented separately in the last two columns of Table 1. Average ozone mixing ratio exhibits pronounced vertical gradient in spite of rather high elevation of both sites. In Europe distinct vertical gradients are mostly reported for the measurements up to $1200 \mathrm{~m}$ a.s.l. (Chevalier et al., 2007) while the picture is less consistent for more elevated sites (see Table 2).

Comparison of the levels of the surface ozone mixing ratio at KHMS with literature data shows (Table 2), that average ozone level at KHMS (2070 ma.s.1.) for the period 20012004 is close to the observations at Arosa (1840 m a.s.l.). Le Casset (1750 ma.s.1.), another station which is even lower than KHMS has slightly higher average mixing ratio but it is still within the limits of 1 standard deviation of the average estimate (Chevalier et al., 2007). Comparing KHMS ozone levels with the data reported for USA sites by Jaffe 
Table 1. Summary of the position of the measuring sites and statistical characteristics of the hourly averaged surface ozone mixing ratios based on the measurements in 1990-2006 at JFJ and KHMS. The last two columns show the statistical characteristics of ozone variability at JFJ and KHMS for the period 2005-2006 (marked with*).

\begin{tabular}{lllll}
\hline & JFJ & KHMS & JFJ $^{*}$ & KHMS $^{*}$ \\
\hline latitude, N & 46.55 & 43.70 & & \\
longitude, E & 7.98 & 42.70 & & \\
altitude, m a.s.l. & 3580 & 2070 & & 80 \\
$N$ valid measurements $(\%)$ & 93 & 66 & 94 & 3.6 \\
minimum, ppb & 2.9 & 3.2 & 17.6 & 113.3 \\
maximum, ppb & 295.6 & 113.3 & 93.3 & $40.0( \pm 7.9)$ \\
mean, ppb $( \pm \sigma)$ & $51.1( \pm 10.5)$ & $43.7( \pm 8.7)$ & $52.8( \pm 9.5)$ & 63.1 \\
variance & 109.7 & 76.2 & 90.8 & \\
skewness $( \pm \sigma)$ & $0.488( \pm 0.007)$ & $0.154( \pm 0.008)$ & $0.37( \pm 0.02)$ & $0.09( \pm 0.02)$ \\
linear trend based on hourly & +0.465 & -0.650 & & \\
mixing ratios $( \pm \sigma)$, ppb/year & \pm 0.006 & \pm 0.006 & & \\
\hline
\end{tabular}

Table 2. Comparison of average ozone mixing ratios at JFJ and KHMS with observations at the other high altitude sites reported in literature.

\begin{tabular}{|c|c|c|c|c|c|}
\hline site & coordinate & altitude, $\mathrm{m}$ & time of measurements & $\begin{array}{l}( \pm \sigma) \\
\text { ozone average }, \mathrm{ppb}\end{array}$ & reference \\
\hline Davos & $46.78^{\circ} \mathrm{N}, 9.82^{\circ} \mathrm{E}$ & 1638 & 2001-2004 & $42.0 \pm 7.1$ & Chevalier et al., 2007 \\
\hline Arosa & $46.77^{\circ} \mathrm{N}, 9.67^{\circ} \mathrm{E}$ & 1840 & 2001-2004 & $42.3 \pm 8.2$ & Chevalier et al., 2007 \\
\hline Wengernalp & $46.57^{\circ} \mathrm{N}, 7.12^{\circ} \mathrm{E}$ & 1890 & 2001-2004 & $46.8 \pm 7.1$ & Chevalier et al., 2007 \\
\hline Monte Cimone & $44.18^{\circ} \mathrm{N}, 10.70^{\circ} \mathrm{E}$ & 2165 & 2001-2004 & $52.8 \pm 9.0$ & Chevalier et al., 2007 \\
\hline Sonnblick & $47.05^{\circ} \mathrm{N}, 12.95^{\circ} \mathrm{E}$ & 3106 & 2001-2004 & $51.4 \pm 6.5$ & Chevalier et al., 2007 \\
\hline Jungfraujoch & $46.55^{\circ} \mathrm{N}, 7.98^{\circ} \mathrm{E}$ & 3580 & 2001-2004 & $53.3 \pm 6.8$ & Chevalier et al., 2007 \\
\hline Kislovodsk HMS & $43.7^{\circ} \mathrm{N}, 42.7^{\circ} \mathrm{E}$ & 2070 & 2001-2004* & $42.2 \pm 7.8$ & this study \\
\hline Lassen N.P., CA & $40.51^{\circ} \mathrm{N}, 121.61^{\circ} \mathrm{W}$ & 1756 & $10 / 87-8 / 04$ & $43.3^{* *}$ & Jaffe and Ray, 2007 \\
\hline Centennial, WY & $41.41^{\circ} \mathrm{N}, 106.21^{\circ} \mathrm{W}$ & 3178 & 7/89-12/04 & $51.1^{* *}$ & Jaffe and Ray, 2007 \\
\hline Craters of the Moon, ID & $43.51^{\circ} \mathrm{N}, 113.61^{\circ} \mathrm{W}$ & 1815 & $10 / 92-12 / 04$ & $44.0^{* *}$ & Jaffe and Ray, 2007 \\
\hline Canyonlands N. P., UT & $38.51^{\circ} \mathrm{N}, 109.81^{\circ} \mathrm{W}$ & 1809 & 8/92-12/04 & $48.0^{* *}$ & Jaffe and Ray, 2007 \\
\hline Jungfraujoch & $46.55^{\circ} \mathrm{N}, 7.98^{\circ} \mathrm{E}$ & 3580 & $1 / 90-12 / 04^{* * *}$ & $51.0 \pm 10.2$ & this study \\
\hline Kislovodsk HMS & $43.70^{\circ} \mathrm{N}, 42.70^{\circ} \mathrm{E}$ & 2070 & $1 / 90-12 / 04^{* * *}$ & $43.9 \pm 8.7$ & this study \\
\hline
\end{tabular}

* Selected subset (overlapping time period);

** For American sites daytime data (10:00-18:00 LST) are reported;

*** Similar to the American sites the day hours only (10:00-18:00 LST) are selected.

and Ray (2007) we can find comparable mixing ratios (see Table 2) reported for Craters of the Moon, ID (1815 m a.s.1.) and Yellowstone N. P., WY (2400 m a.s.1.). Hence, the average ozone mixing ratio observed at Caucasus region is consistent with the other observations at the elevated sites of the northern mid-latitudes (in the altitude range 1600-
$2400 \mathrm{~m}$ a.s.1.). Substantial variability of the average ozone mixing ratios is reported among the sites at altitudes of 1600 $2800 \mathrm{~m}$ a.s.1., which may be connected with different pollution levels at the individual stations and different impacts of complex topography. Nevertheless only if the altitude of the site is higher than approximately $3000 \mathrm{~m}$ a.s.l. average ozone 
mixing ratios usually exceed $50 \mathrm{ppb}$. Among the less elevated stations the average mixing ratio higher than $50 \mathrm{ppb}$ is only reported for Monte Cimone, which is strongly affected by ozone and precursors advection from the heavily polluted Po basin (Campana et al., 2005; Cristofanelli et al., 2007).

The variance of the hourly mixing ratios is bigger at JFJ in comparison with the Caucasian station (Table 1) both for the whole data series and for the period 2005-2006. Minimum hourly mean mixing ratios are comparable for JFJ and KHMS for the whole series, while in 2005-2006 ozone minimum values at JFJ are higher than the ones at KHMS. This may be connected with strong positive trend of the surface ozone mixing ratio at JFJ, which is more pronounced for minimum values (Brönnimann et al., 2002).

The frequency distribution of the hourly mean mixing ratios is close to the Gaussian probability function for KHMS (shown by skewness of the distribution function in Table 1, and Fig. 3). The distribution of the hourly mean mixing ratios is asymmetric for JFJ and can be approximated by a superposition of two Gaussian functions (the characteristics of the distribution are given in Fig. 3). Despite of the similarity of the KHMS' distribution function to the Gaussian shape, there are still some signs of the secondary peak which looks like a "shoulder" in the range of bigger mixing ratios (Fig. 3). The presence of two maxima in the distribution function shows that different mechanisms might control particular concentration levels, associated for example with stratosphere-troposphere exchange versus long-range transport on the large scale or circulations patterns on a local scale. Double peak ozone distributions function were also reported for Mt. Cimone and Mt. Waliguan (Lee et al., 2007; Wang et al., 2006) with the first peak centering at $43 \mathrm{ppb}$ and $45 \mathrm{ppb}$ correspondingly. These values are similar to the main peaks of the ozone distributions at the sites considered in this paper (45.5 ppb at JFJ and $43.4 \mathrm{ppb}$ at KHMS).

\subsection{Seasonal variations of ozone mixing ratios}

The seasonal cycles of ozone mixing ratios at KHMS and JFJ show higher ozone values in the warm season (for both locations two maxima are pronounced) and lower values in the cold season as typically observed at rural and remote sites (including high altitude stations) in northern mid-latitudes (see e.g. Tarasova et al., 2007), except the remarkably low values reported at KHMS in September and October in 1996 (Fig. 2a). Spring and summer maxima in the seasonal cycle are more distinguishable for KHMS than for JFJ. The highest ozone mixing ratios in the Caucasus and the Alps are observed between March and August, depending on a particular year (Fig. 4). This period overlaps with the time when mountain venting occurs (usually effective from May till September), which transports air from lower altitudes by convection to high altitudes (Henne et al., 2004, 2005). High ozone values observed in the summer 2003 at JFJ are connected with the very high temperatures in this summer, which seem not
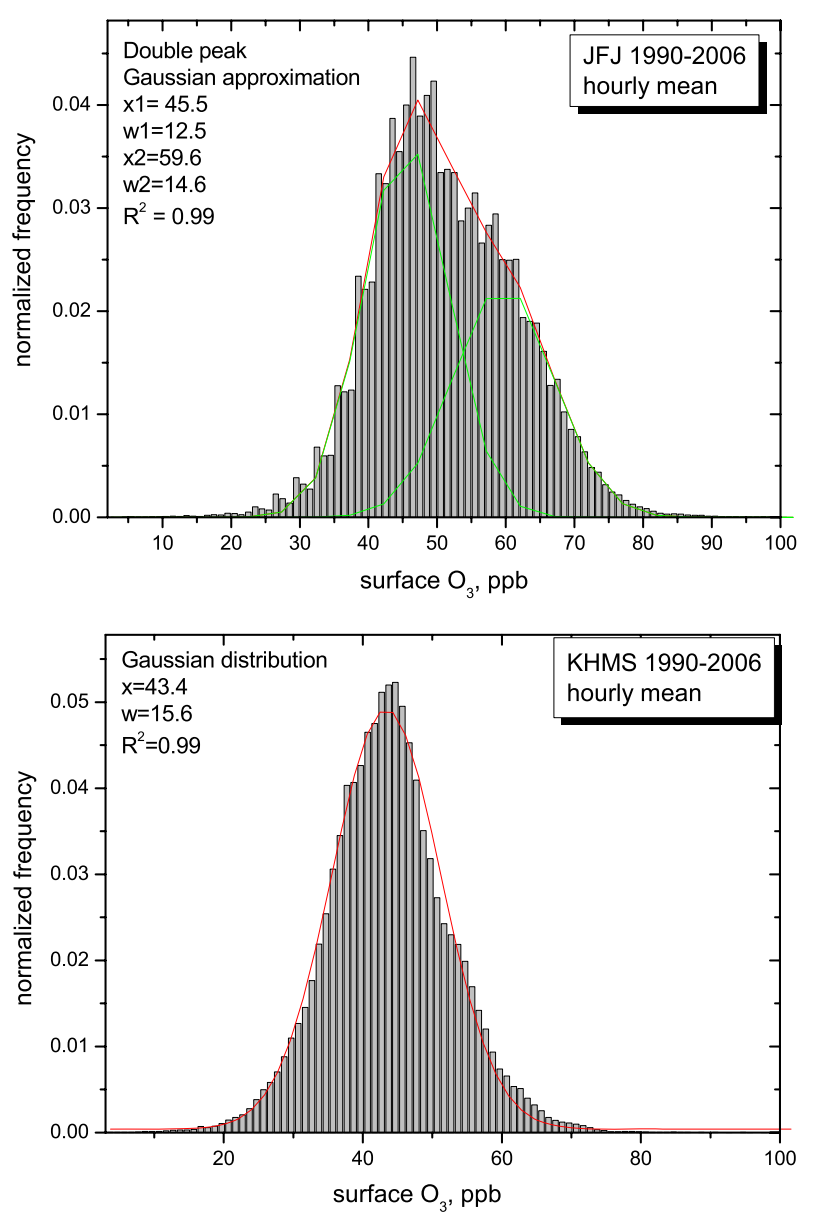

Fig. 3. Distribution functions of the surface ozone mixing ratio at JFJ (a) and KHMS (b). Gaussian approximations are given for the distribution functions calculated on the long-term measurements. In the graphs " $x$ " corresponds to the distribution curve center and " $w$ " gives a fit curve width.

only have affected ozone in the European Planetary Boundary layer (e.g. Ordóñez et al., 2005) but also ozone concentrations at JFJ. Record low ozone values are found at KHMS in September/October 1996 (the low values are confirmed by two instruments operated simultaneously) and the highest mixing ratios are registered in summer at JFJ in 2006.

Rather extreme amplitudes of the seasonal cycles are observed at KHMS in 1996 and 2003 (27.7 ppb and $20 \mathrm{ppb}$ ). Ignoring these particular years the average amplitude of the seasonal cycle at Caucasian station has a tendency to decrease from $18.3 \mathrm{ppb}$ in 1990-1992 to $12.8 \mathrm{ppb}$ in 1997-2001 (Fig. 3). This change in seasonal variation amplitude is related to a strong decrease in spring/summer values whereas the decrease in ozone levels in the cold season is much smaller (Senik and Elansky, 2001; Tarasova et al., 2003). 
Table 3. Comparison of trends with $1 \sigma$ standard deviation for different vertical subsets at KHMS for the period 1991-2001 (average monthly frequency is given in the brackets in \%).

\begin{tabular}{lrrrrr}
\hline & annual & DJF & MAM & JJA & SON \\
\hline original data set monthly mean & $-0.91 \pm 0.17$ & $-0.60 \pm 0.24$ & $-0.98 \pm 0.25$ & $-1.16 \pm 0.33$ & $-0.64 \pm 0.27$ \\
FT cases & & & & & \\
$p<400 \mathrm{hPa}$ & $-0.96 \pm 0.18(17.8)$ & $-0.61 \pm 0.26(19.6)$ & $-1.09 \pm 0.27(18.1)$ & $-1.14 \pm 0.36(11.4)$ & $-0.74 \pm 0.30(22.0)$ \\
$p<500 \mathrm{hPa} \& \mathrm{PV}>1.3 \mathrm{PVU}$ & $-0.79 \pm 0.20(7.1)$ & $-0.37 \pm 0.28(9.7)$ & $-0.75 \pm 0.27(7.7)$ & $-0.98 \pm 0.42(3.4)$ & $-0.68 \pm 0.31(7.7)$ \\
$p<500 \mathrm{hPa} \& \mathrm{PV}>1.6 \mathrm{PVU}$ & $-0.82 \pm 0.20(5.5)$ & $-0.48 \pm 0.29(7.8)$ & $-0.71 \pm 0.29(5.4)$ & $-1.15 \pm 0.42(2.7)$ & $-0.64 \pm 0.35(5.6)$ \\
$p<500 \mathrm{hPa} \& \mathrm{PV}>2 \mathrm{PVU}$ & $-0.78 \pm 0.21(4.4)$ & $-0.57 \pm 0.30(6.1)$ & $-0.67 \pm 0.29(4.3)$ & $-0.95 \pm 0.50(2.4)$ & $-0.70 \pm 0.42(4.3)$ \\
PBL cases & & & & & \\
more than 1 contact with PBL east of 10 W & $-0.84 \pm 0.18(69.6)$ & $-0.58 \pm 0.25(41.9)$ & $-0.86 \pm 0.25(84.2)$ & $-1.17 \pm 0.33(93.3)$ & $-0.52 \pm 0.27(58.9)$ \\
2 of the last 5 days in contact with PBL & $-0.82 \pm 0.20(15.8)$ & $-0.67 \pm 0.27(9.8)$ & $-0.81 \pm 0.33(15.0)$ & $-1.12 \pm 0.34(26.3)$ & $-0.49 \pm 0.35(11.6)$ \\
\hline
\end{tabular}
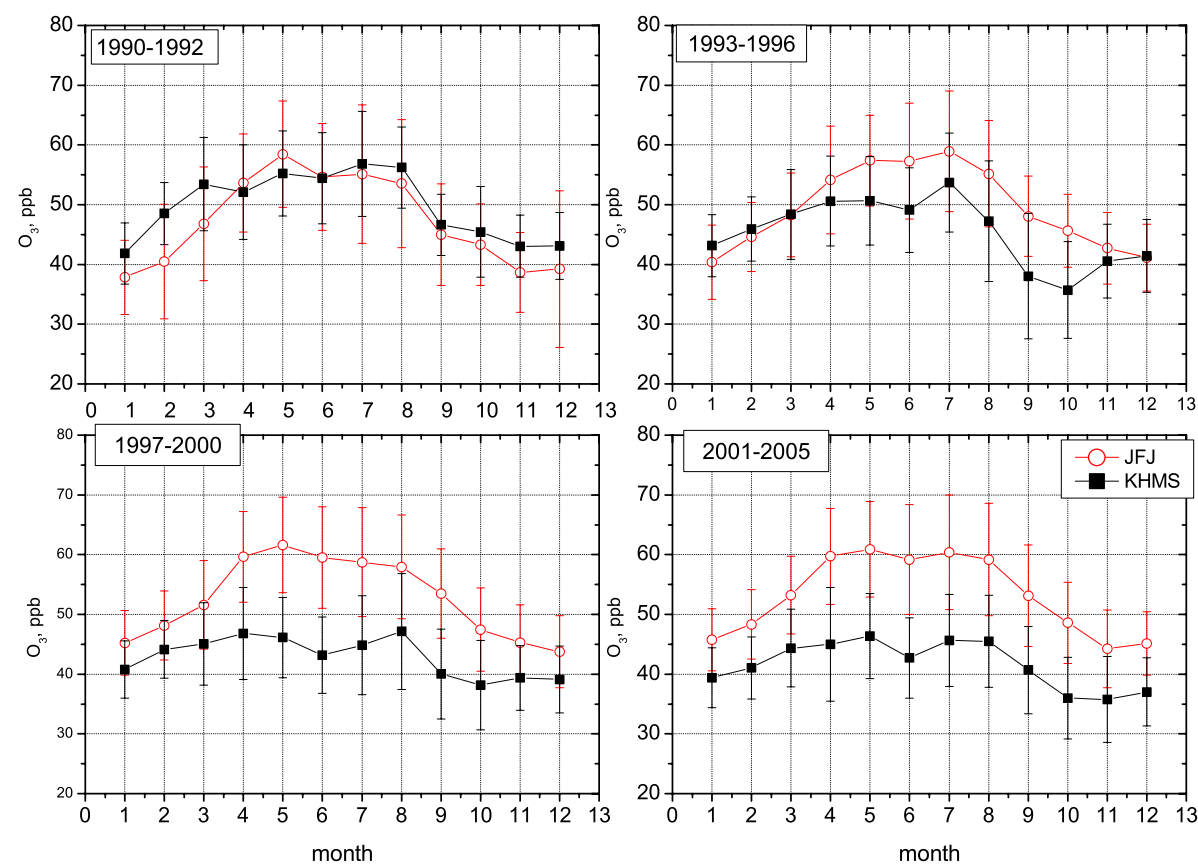

Fig. 4. Comparison of the ozone seasonal cycle at JFJ and KHMS averaged for the different time periods (based on the original hourly mean data). Year 2006 is not included in the last period due to substantially different shape of the seasonal variations at both sites (strong single summer maximum).

The seasonal cycle of the surface ozone concentration at $\mathrm{JFJ}$ is also characterized by a spring-summer maximum. The amplitude of the seasonal variations (difference between annual maximum and annual minimum) at JFJ has a substantial interannual variability, being high in 1990 (29.7 ppb), 1994 (26.4 ppb), 2003 (24.3 ppb) and 2006 (23.9 ppb). The average amplitude of the seasonal variations changed from $22 \mathrm{ppb}$ in $1990-1992$ to $20.1 \mathrm{ppb}$ in 1997-2001. However, this change in the amplitude of the seasonal cycle can not be regarded as significant due to its strong inter-annual variability. Note that amplitude of the seasonal cycle is bigger at JFJ than at KHMS, showing a high stability of the surface ozone mixing ratios in the Caucasus region in spite of the lower altitude of Caucasian site.
The origin of the spring and summer ozone maxima at rural and remote sites has been discussed since many years. Historical records show spring maxima in earlier years (Linvill et al., 1980; Monks, 2000; Nolle et al., 2005), although the shape of the seasonal cycle is likely to be sensitive to pollution conditions (see e.g. Scheel et al., 2003). In the earlier time surface ozone maximum was typically found in May (e.g. at Arosa) and it was attributed to the mixing with the stratospheric air (e.g. Götz and Volz, 1951; Staehelin et al., 1994). Surface measurements and ozone soundings at rural and semi-polluted sites in North America and Europe from the 1980s (Logan, 1985) and the 1990s (Tarasova et al., 2007 and references therein) often show a shift of the seasonal maximum to summer, which is commonly attributed 

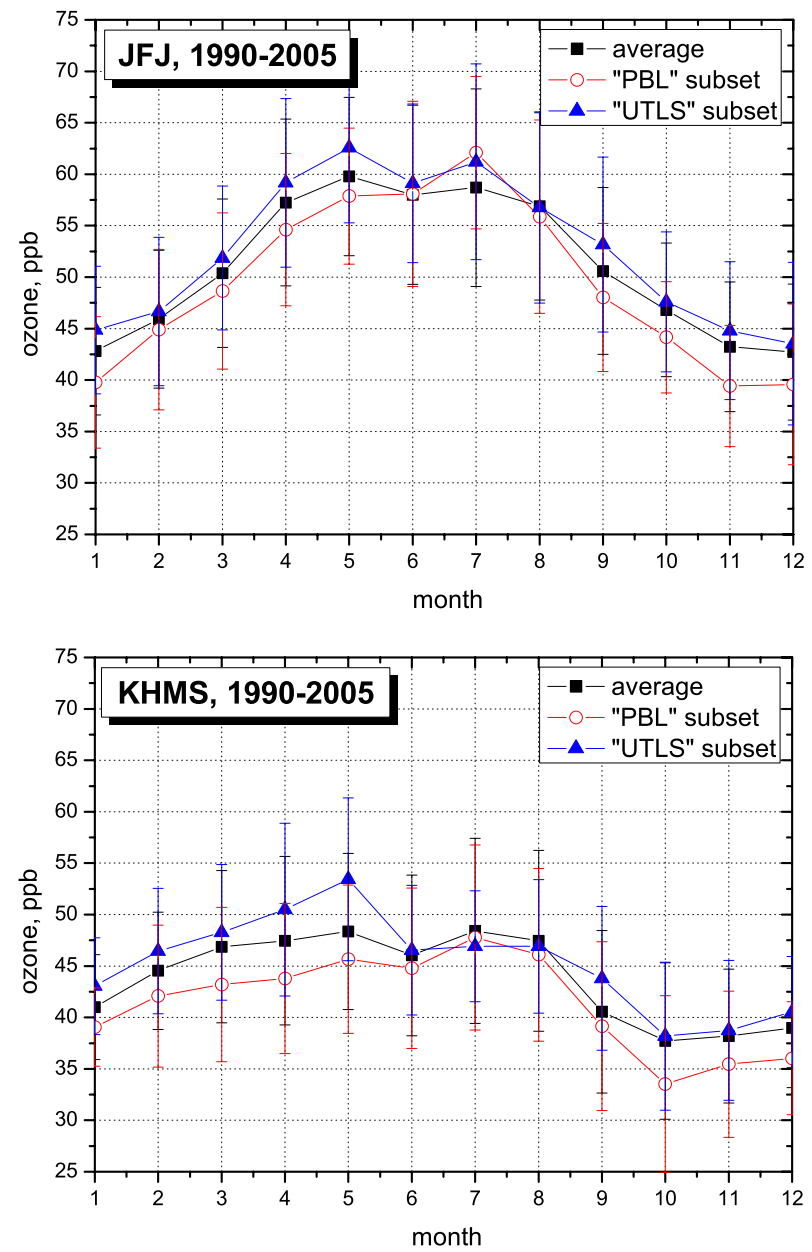

Fig. 5. Averaged ozone seasonal cycles for the subsets filtered on the vertical air mass origin and the average non-filtered seasonal cycles for the period 1990-2005 for JFJ (a) and KHMS (b).

to photochemical ozone production related to anthropogenic emissions of ozone precursors.

When analyzing the variability and the seasonal cycle it is important to consider the role of different processes. Figure 5 shows the results of backward trajectory analyses attempting to discriminate between the effect of mixing with the stratospheric air and recent contact with the (polluted) planetary boundary layer. Air parcels defined as "UTLS" (i.e. PV values larger than 2 PVU and air parcel altitude is higher than $500 \mathrm{hPa}$ at least once along the trajectory) show a general tendency to have higher ozone mixing ratios than the averages, while the air parcels defined as having contact with the PBL (at least 2 days of the last 5 before arrival at the station the air parcel was inside PBL, which altitude is retrieved from reanalysis data along the trajectory) have ozone mixing ratios a bit lower than the averages, except for July. Average ozone mixing ratio in the UTLS subset is only slightly higher than unfiltered monthly mean mixing ratio, which suggests strong mixing of the stratospheric air with the tropospheric air be-
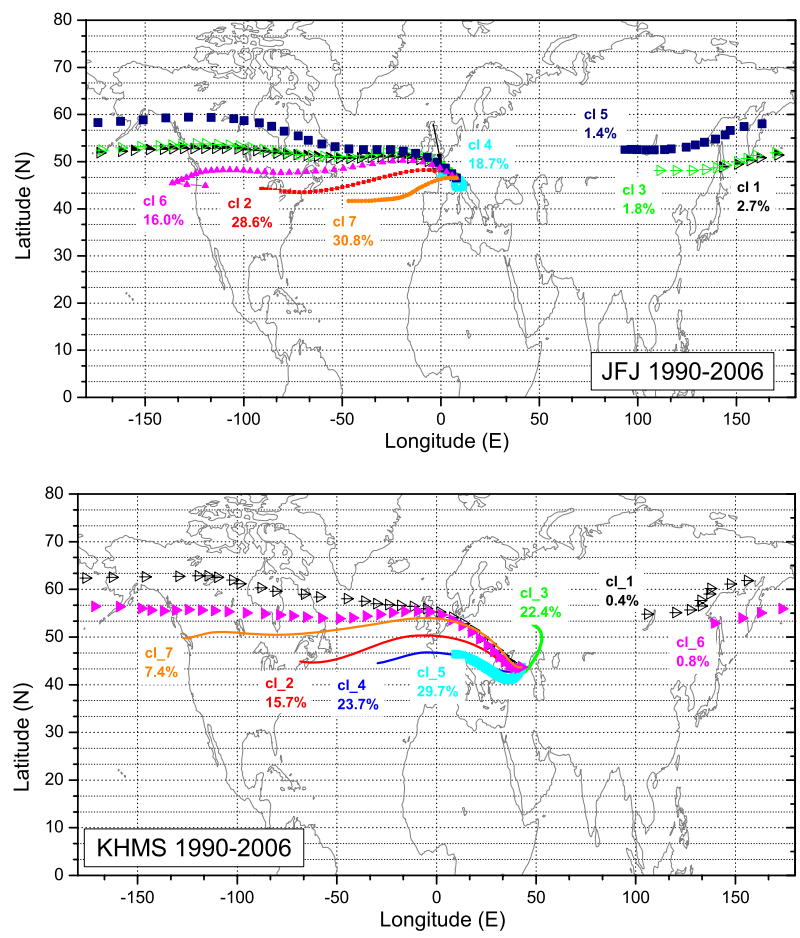

Fig. 6. Centers of the main air transport clusters at JFJ (a) and KHMS (b) for the period 1990-2006 based on the 3-D LAGRANTO 10 days back trajectories. Numbers at the beginning of the lines show an average frequency to observe the transport in the selected cluster for the whole period. Note that these numbers are seasonally dependent.

fore the air masses reach the measurement site. The strongest positive deviation of the mixing ratio from unfiltered average is observed for the "UTLS" subset at both sites in May, most probably associated with the highest seasonal ozone levels in the upper free troposphere/lowermost stratosphere in the northern extratropics (total ozone seasonal maximum in the northern mid-latitudes usually peaks between March and May as reported by Staehelin et al. (2001). Monthly mean mixing ratios in the PBL subset are a bit lower than average during the cold season, which probably reflects the effect of ozone poor PBL air caused by ozone dry deposition and titration with NO.

The major transport pathways to each station are presented in Fig. 6. For both locations western clusters are prevailing. However, western clusters are affected by the different areas of impact, i.e. the sampling is more often over the Atlantic Ocean for JFJ and over different European regions for KHMS. It should be noted that the clusters representing the transport of the longest distance are observed in less than 5\% of all trajectories for both locations. Substantial numbers of cases (around $18 \%$ at JFJ and $22 \%$ at KHMS) correspond to the transport on the regional/local scale. 

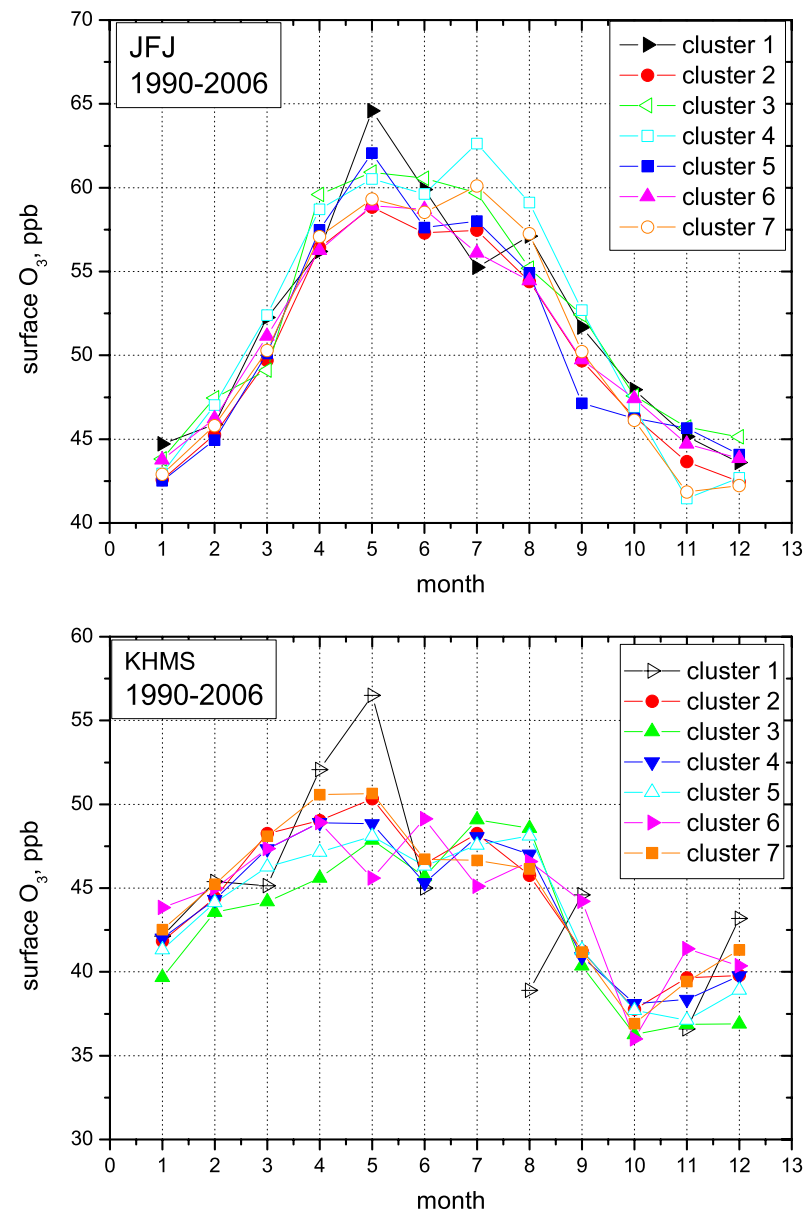

Fig. 7. Averaged seasonal cycles of the surface ozone mixing ratio in the different clusters of the air transport at (a) JFJ and (b) KHMS. Average cycles are calculated for the period 1990-2006. The colors on the graph are the same as the colors for the cluster centers (Fig. 6). Standard deviations are not shown here to prevent the graphs from overloading with information.

Average surface ozone seasonal cycles are calculated for the different clusters of the horizontal advection (Fig. 7). Two important features can be seen in the graphs, which are similar for both sites (JFJ and KHMS). The highest spring maximum is observed in May in the clusters, originating at East Asia (cluster 1 for KHMS and cluster 5 for JFJ). For the other clusters representing long-range transport and traveling in the upper part of the troposphere the seasonal variations are very similar, i.e. showing a spring maximum (clusters 5 and 3 for JFJ and cluster 6 for KHMS). However, the significance of the relative contributions of the mentioned clusters to the average seasonal cycles is small due to their low frequencies (less than 3\%).

The second important feature, which is the same for both locations, consists of larger ozone concentrations in summer than in spring in the clusters of the local/regional transport (cluster 4 for JFJ and cluster 3 for KHMS). These clusters
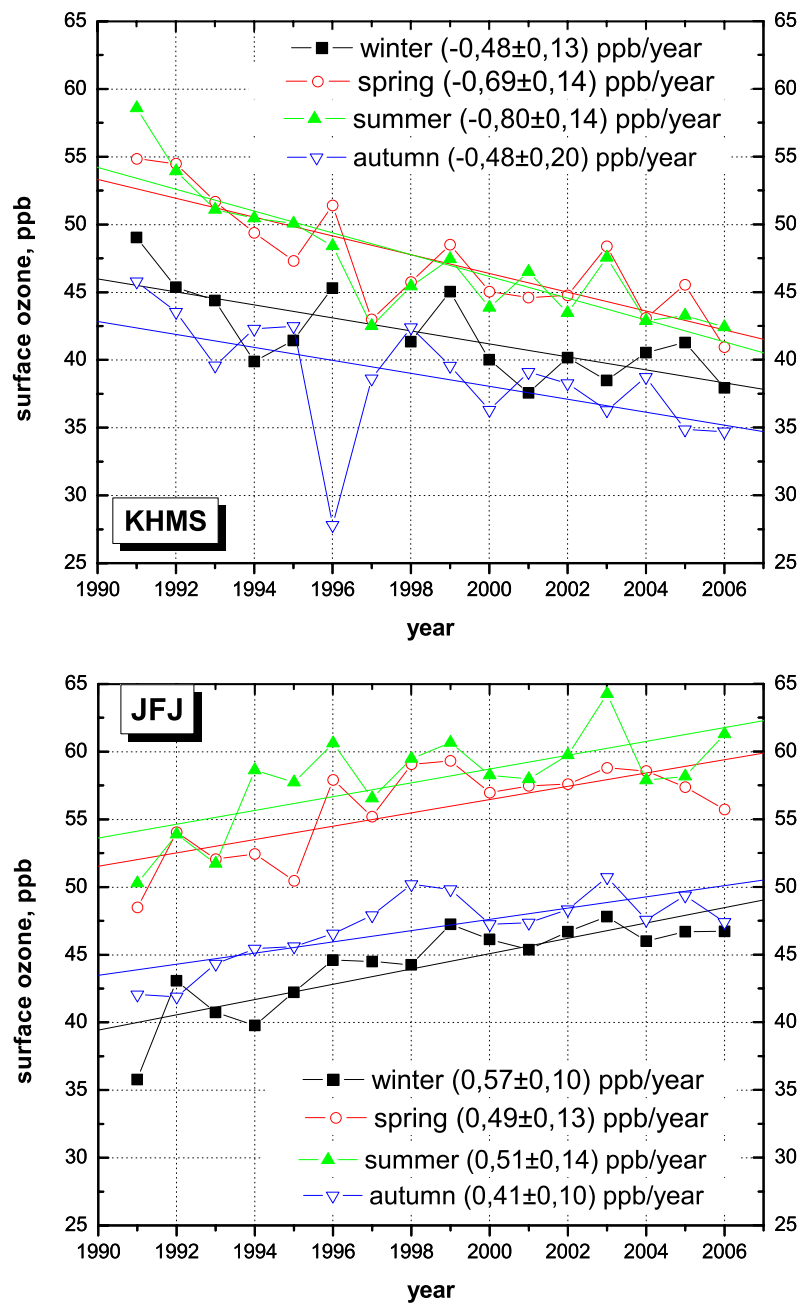

Fig. 8. Seasonally mean surface ozone mixing ratios at KHMS (a) and JFJ (b) and linear trends for the period 1991-2006.

for both stations have the highest frequency of the contact with the polluted continental PBL and are associated with slow transport (stagnation condition). This summer maximum in the local clusters is associated with ozone photochemical production in the polluted air. Slight excess of the summer maximum above the spring one is observed in the other clusters, which spent long time over the continent (for example, in cluster 7 for JFJ). For the clusters impacted by the European PBL arriving at KHMS spring and summer maxima are of comparable magnitude.

\subsection{Trend analysis of ozone mixing ratios}

Long-term trends of the surface ozone mixing ratio at the two sites have different signs and depend on season for both locations (Fig. 8). In the following chapter the trends are analyzed at Kislovodsk (Sect. 3.3.1) and at Jungfraujoch (Sect. 3.3.2) making use of the data obtained by the backward trajectory analysis. Earlier ozone trend analysis for JFJ has 

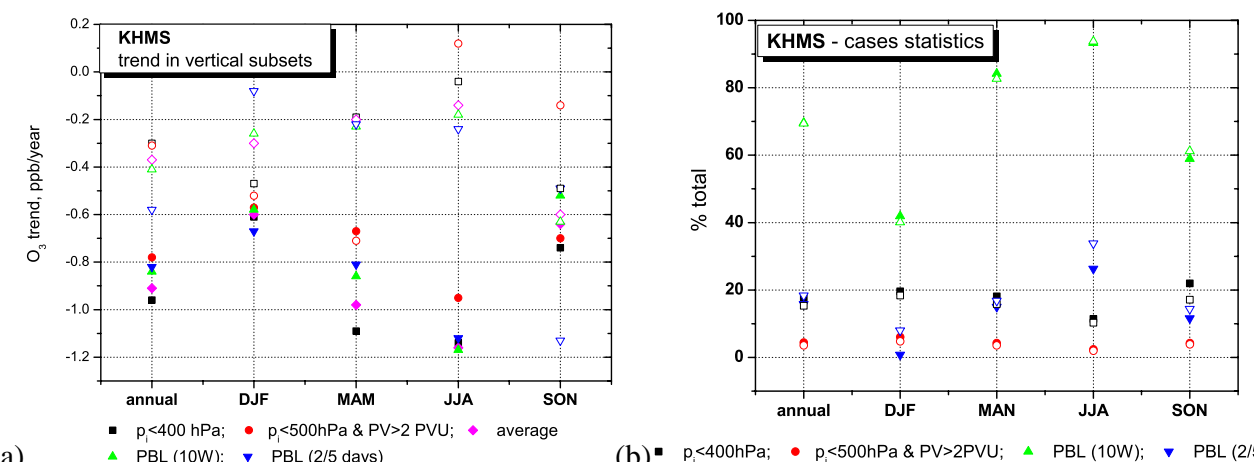

(a)

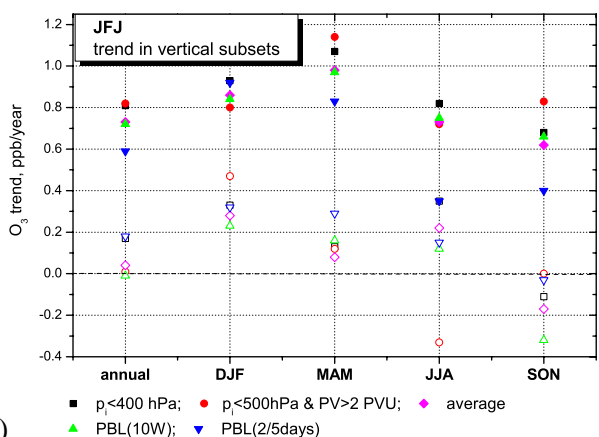

(b)

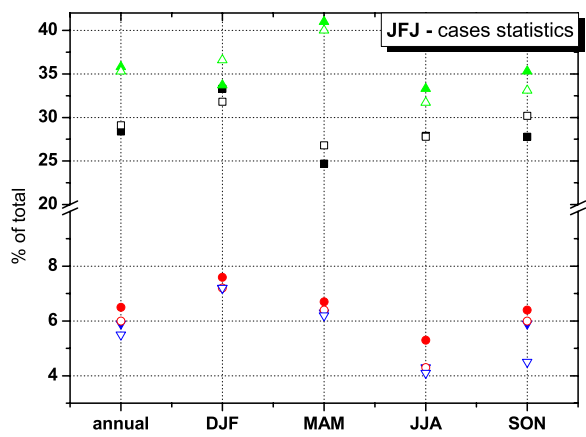

(d) - $\mathrm{p}_{\mathrm{i}}<400 \mathrm{hPa} ; \quad \cdot \mathrm{p}_{\mathrm{i}}<500 \mathrm{hPa} \& \mathrm{PV}>2 \mathrm{PVU} ; \quad \triangle \mathrm{PBL}(10 \mathrm{~W}) ; \quad \boldsymbol{P B L}(2 / 5$ days $)$

Fig. 9. Trends summary for different vertical subsets (Tables 3, 4, 7, 8) for KHMS (a) and JFJ (c). (b) and (d) show the respective statistics of the cases in which the corresponding criteria given under the plot is fulfilled along the trajectory. The weaker criteria include the stricter ones on the same parameter. Statistics of the FT and PBL cases is presented for different periods in $\%$ of the total observational time. More detailed cases encoding is given in the text. For the free troposphere/low stratosphere cases and contact with the PBL over the continent total 10 days back trajectories are used, while for the strict PBL contact criterion only 5 days back trajectories are used. Solid symbols correspond to the respective values (trends or cases statistics) in 1991-2001, and open symbols refer to the period 1997-2006.

been presented by Schuepbach et al., 2001; Brönnimann et al., 2000, 2002, and Ordonez et al., 2007 and for Kislovodsk High Mountain Station by Senik and Elansky, 2001; Senik et al., 2005; and Tarasova et al., 2003. Here we also intend to explore the mechanisms causing the different signs of the trends at two stations by applying the same approach (air masses separation in accordance with their origin) to both sites.

The trends are calculated for different time periods, namely 1991-2001 and 1997-2006 (described in the chapter "Measurements and Methods") and transport subsets. Vertical subsets are discussed first enabling to use the main findings in the interpretation of the trends in the clusters of the horizontal advection. The frequencies of the cases for each particular subset did not change strongly allowing to explore the systematic long-term ozone changes, Figs. 9b, d).

\subsubsection{Trend analysis of ozone measurements at Kislovodsk High Mountain Station}

Ozone trends at KHMS separated by the vertical transport classes (including planetary boundary layer contact and stratospheric origin, see Table 3 and Fig. 9a) are negative and statistically significant in 1991-2001 for all selected classes. Differences between trends in FT and PBL classes are insignificant. Maximum negative trends at KHMS (Table 3) occur in summer, while minimum negative trends are observed in winter (FT cases) or in autumn (PBL cases). The decrease of ozone in summer can be explained by ozone precursor emission reductions which occurred in 90s in Western Europe due to air pollution regulations whereas ozone precursor emissions strongly decreased in the Newly Independent States of the former USSR because of the breakdown accompanied by an economical crisis. KHMS is situated deep in the continent, hence a probability of contact with the planetary boundary layer anywhere over the continent is much higher for KHMS than for JFJ. The area from which the air is sampled in the subset of the strongest PBL criteria ( 2 days of the last 5 before arrival to the station spent in the PBL) covers mostly the northern Caucasus region (not shown here). The trends in the FT subsets at KHMS are also negative which contrasts the findings for JFJ. The explanation of the winter decrease is less obvious. A decrease in NO emissions is expected to increase ozone concentrations in winter, while the trend values for the cold season are only less pronounced than for summer, but still negative. Possibly 
Table 4. Comparison of trends with $1 \sigma$ standard deviation for different vertical subsets at KHMS for the period 1997-2006 (average monthly frequency is given in the brackets in \%).

\begin{tabular}{|c|c|c|c|c|c|}
\hline & annual & DJF & MAM & JJA & SON \\
\hline Original data set monthly mean & $-0.37 \pm 0.14$ & $-0.30 \pm 0.25$ & $-0.20 \pm 0.20$ & $-0.14 \pm 0.24$ & $-0.60 \pm 0.21$ \\
\hline \multicolumn{6}{|l|}{ FT cases } \\
\hline$p<400 \mathrm{hPa}$ & $-0.30 \pm 0.15(15.3)$ & $-0.47 \pm 0.28(18.4)$ & $-0.19 \pm 0.22(15.8)$ & $-0.04 \pm 0.25(10.3)$ & $-0.49 \pm 0.20(17.1)$ \\
\hline$p<500 \mathrm{hPa} \& \mathrm{PV}>1.3 \mathrm{PVU}$ & $-0.41 \pm 0.17(5.9)$ & $-0.51 \pm 0.29(8.2)$ & $-0.58 \pm 0.30(6.5)$ & $0.00 \pm 0.35(2.8)$ & $-0.43 \pm 0.21(6.4)$ \\
\hline$p<500 \mathrm{hPa} \& \mathrm{PV}>1.6 \mathrm{PVU}$ & $-0.42 \pm 0.18(4.5)$ & $-0.60 \pm 0.31(6.3)$ & $-0.70 \pm 0.35(4.7)$ & $0.07 \pm 0.34(2.2)$ & $-0.41 \pm 0.26(4.8)$ \\
\hline $\begin{array}{l}p<500 \mathrm{hPa} \& \mathrm{PV}>2 \mathrm{PVU} \\
\text { PBL cases }\end{array}$ & $-0.31 \pm 0.18(3.6)$ & $-0.52 \pm 0.31(4.8)$ & $-0.71 \pm 0.36(3.6)$ & $0.12 \pm 0.32(2.0)$ & $-0.14 \pm 0.29(3.9)$ \\
\hline more than 1 contact with PBL east of $10 \mathrm{~W}$ & $-0.41 \pm 0.16(69.4)$ & $-0.26 \pm 0.30(40.1)$ & $-0.23 \pm 0.20(82.7)$ & $-0.18 \pm 0.25(93.7)$ & $-0.63 \pm 0.24(61.2)$ \\
\hline 2 of the last 5 days in contact with PBL & $-0.58 \pm 0.19(18.4)$ & $-0.08 \pm 0.37(8.0)$ & $-0.22 \pm 0.25(16.8)$ & $-0.24 \pm 0.28(33.8)$ & $-1.13 \pm 0.36(14.4)$ \\
\hline
\end{tabular}

the following reasons can explain at least partially these findings: 1) the NO decrease in regional emissions was probably lower than the VOC decrease, because the largest regional pollution sources in the Caucasus region can be attributed to the oil industry; 2) mixing processes are not described in LAGRANTO trajectories but the field of the ozone precursors as well as of ozone over the continent is not uniform which might be particularly important for complex terrain and may lead to falsification of the FT cases. As mentioned in the introduction the structure of the large scale motions at KHMS is more complicated than at JFJ, and hence dynamical reasons for the trend negative bias not seen in the trajectory analysis cannot be ruled out which needs further analysis. Note, that for KHMS total time of the contact with the upper troposphere/lower stratosphere (PV>2 PVU and $p<500 \mathrm{hPa}$ ) is (as expected according to its altitude) much smaller compared to JFJ in 1991-2001 (31 578 total hours at KHMS against $64038 \mathrm{~h}$ at JFJ), and therefore the effect of increasing ozone concentration in the free troposphere over the Atlantic (see Sect. 3.3.2.) is expected to be less important for KHMS than for JFJ.

Ozone trends in the different vertical subsets are much smaller at KHMS in 1997-2006 in comparison with the earlier period (Table 4, Fig. 9a). Annual mean PBL trends are much more negative than FT trends. However, such differences strongly depend on season (winter and spring trends in FT cases are more negative than in the PBL cases demonstrating stronger negative bias in the free troposphere). The number of cases with contact with the PBL at KHMS has increased in 1997-2006 in comparison with the period 19912006 (from an annual average of $15.8 \%$ to $18.4 \%$ ) suggesting an increase of the PBL impact on the trends at KHMS. Increase of the time which air masses spent in the PBL should on one hand decrease ozone concentration due to dry deposition on the other hand the probability to pick up ozone and its precursors should be higher, and therefore these two processes (dry deposition and photochemical production) may have compensated each other to an unknown extent.
Figure 9a shows that the seasonalities of the trends for the two periods (1991-2001 vs. 1997-2006) at KHMS are different (compare also Tables 3 and 4). Summer trends (among the most negative in the earlier period) are close to 0 in the later period, which can indicate a change from decreased ozone summer production to the stabilization of summer production. Moreover the most significant changes of the seasonal trends occurred in summer (from the range $-1.2 \ldots-0.9 \mathrm{ppb} / \mathrm{year}$ in 1991-2001, to the range $-0.24 \ldots+0.12 \mathrm{ppb} /$ year in 1997-2006). Winter trends in the strictest PBL subset (the lowest rows in Tables 3 and 4) have the same tendency and changed from $-0.67 \mathrm{ppb} / \mathrm{year}$ in 1991-2001 to the least negative among all subsets in 19972007 ( $-0.08 \mathrm{ppb} / \mathrm{year})$. The ratio of the summer and winter trends at KHMS during 1997-2006 more corresponds to the scenario of emissions increase (more negative trend in winter and less negative and even positive trend in summer). Ozone trends in the strictest FT subsets (PV > 2 PVU) remain negative in 1997-2006 while the total time, which trajectories spent in the region falling under the mentioned criterion (31 578 h in 1991-2001 against $22980 \mathrm{~h}$ in 1997-2006) has decreased.

The summary of ozone trends in the clusters of horizontal advection is provided in Tables 5 and 6. For the period 19912001 surface ozone trends at KHMS in all clusters and for all seasons are negative and statistically significant (Table 5) with a somewhat wider range than in the vertical subsets. Annual trends are in the range from -1.09 to $-0.7 \mathrm{ppb} /$ year. For the annual mean values the most negative trend is observed (among the most contributing clusters) in the cluster 4, covering the Southern and Central Europe and originating over Central Atlantic. This ozone decrease may be connected with a decrease of ozone precursors in the area of Central and Southern Europe consistent with strong emissions regulations of ozone precursors. A similar negative trend is found in cluster $5(-0.89 \mathrm{ppb} / \mathrm{year})$, which originates from Central Europe, confirming the idea that the part of the negative trend at KHMS may be connected not only with local emissions decrease (see below) but also can be impacted by the air advection from Western Europe (consistent with 
Table 5. Comparison of trends with $1 \sigma$ standard deviation for different horizontal clusters of the air mass advection at KHMS for the period 1991-2001 (average monthly frequency is given in the brackets as percent of total number of cases).

\begin{tabular}{rrrrrr}
\hline & annual & DJF & MAM & JJA & SON \\
\hline cluster 1 & $-0.70 \pm 0.47(1.4)$ & $0.44 \pm 0.59(1.8)$ & $-1.38 \pm 1.04(1.2)$ & $-4.33 \pm 4.43(1.2)$ & $-0.63 \pm 0.87(1.1)$ \\
cluster 2 & $-0.78 \pm 0.18(16.8)$ & $-0.56 \pm 0.25(22.6)$ & $-1.22 \pm 0.31(17.0)$ & $-0.67 \pm 0.35(9.1)$ & $-0.45 \pm 0.29(18.4)$ \\
cluster 3 & $-0.90 \pm 0.21(21.5)$ & $-0.42 \pm 0.29(9.9)$ & $-0.99 \pm 0.32(17.5)$ & $-1.04 \pm 0.38(40.9)$ & $-0.70 \pm 0.36(17.6)$ \\
cluster 4 & $-0.98 \pm 0.18(23.8)$ & $-0.78 \pm 0.26(25.2)$ & $-0.96 \pm 0.30(26.7)$ & $-1.43 \pm 0.39(18.8)$ & $-0.51 \pm 0.28(24.6)$ \\
cluster 5 & $-0.89 \pm 0.17(29.3)$ & $-0.62 \pm 0.25(26.7)$ & $-0.80 \pm 0.24(31.5)$ & $-1.29 \pm 0.33(28.4)$ & $-0.62 \pm 0.30(30.5)$ \\
cluster 6 & $-1.09 \pm 0.36(1.6)$ & $-0.06 \pm 0.36(2.1)$ & $-1.85 \pm 1.00(1.5)$ & $-1.40 \pm 1.09(1.2)$ & $-1.09 \pm 0.73(1.2)$ \\
cluster 7 & $-0.80 \pm 0.22(8.6)$ & $-0.62 \pm 0.26(13.2)$ & $-0.75 \pm 0.29(7.4)$ & $-1.06 \pm 0.51(3.6)$ & $-1.23 \pm 0.39(8.7)$ \\
\hline
\end{tabular}

Table 6. Comparison of trends with $1 \sigma$ standard deviation for different horizontal clusters of the air mass advection at KHMS for the period 1997-2006 (average monthly frequency is given in the brackets as percent of total number of cases).

\begin{tabular}{rrrrrr}
\hline & annual & DJF & MAM & JJA & SON \\
\hline cluster 1 & $-0.47 \pm 0.51(1.6)$ & $-1.07 \pm 0.68(1.9)$ & $0.44 \pm 1.43(1.3)$ & no data & $-0.68 \pm 0.90(1.2)$ \\
cluster 2 & $-0.36 \pm 0.17(15.1)$ & $-0.48 \pm 0.26(22.5)$ & $-0.19 \pm 0.27(15.5)$ & $0.06 \pm 0.36(7.4)$ & $-0.67 \pm 0.27(14.6)$ \\
cluster 3 & $-0.36 \pm 0.17(23.7)$ & $-0.51 \pm 0.30(8.7)$ & $-0.22 \pm 0.23(19.9)$ & $-0.30 \pm 0.29(43.7)$ & $-0.43 \pm 0.28(21.6)$ \\
cluster 4 & $-0.18 \pm 0.15(23.8)$ & $-0.22 \pm 0.25(25.8)$ & $-0.09 \pm 0.27(25.4)$ & $0.19 \pm 0.27(18.0)$ & $-0.39 \pm 0.20(26.3)$ \\
cluster 5 & $-0.45 \pm 0.15(30.3)$ & $-0.32 \pm 0.28(27.5)$ & $-0.30 \pm 0.19(32.9)$ & $-0.13 \pm 0.25(29.7)$ & $-0.82 \pm 0.26(31.2)$ \\
cluster 6 & $-0.09 \pm 0.34(2.2)$ & $-0.31 \pm 0.34(3.3)$ & $0.29 \pm 1.10(1.5)$ & $-0.03 \pm 1.90(1.7)$ & $0.08 \pm 0.55(1.2)$ \\
cluster 7 & $-0.57 \pm 0.22(7.8)$ & $-0.40 \pm 0.25(13.2)$ & $-0.56 \pm 0.32(5.8)$ & $-0.53 \pm 0.41(2.8)$ & $-0.46 \pm 0.36(6.8)$ \\
\hline
\end{tabular}

trends values in the subset $p<400 \mathrm{hPa}$, which is strongly impacted by the long range transport). In total clusters 4 and 5 constitute $55 \%$ of the air masses arriving to the station per annum. In summer cluster 3 representing local transport is the most frequent one (accounting for $44 \%$ of transport). North Caucasian region was well known as one of the oldest oil producing regions in the former Soviet Union (refinery region). For the period from 1990 till 1995 oil production in the region decreased nearly 3 times (from around 9 million tons to 3.78 million tons) as reported by the state committee on statistics "Goskomstat" (1999) which means the decrease of accompanying emissions.

The largest deviations of trends between the two periods is observed in summer (Table 5: from -1.43 to $-0.67 \mathrm{ppb} / \mathrm{year}$ ), while winter trends are much closer to each other (from -0.78 to $-0.42 \mathrm{ppb} /$ year). In summer cluster 3 is the most frequent one and ozone trends in this cluster are impacted by regional processes.

Comparing the trends of the surface ozone concentration at KHMS for the period 1997-2006 (Table 6) with the earlier period, we can see substantial decrease of the trends absolute values. For most of the clusters (clusters 2, 3, 4, 5 and 7) trends remain negative and statistically significant. The least negative annual trend is observed in cluster 4 (originating in Central Atlantic), up to $-0.18 \mathrm{ppb} /$ year. Moreover, the most substantial changes of the trends' values and their seasonality are observed in this cluster (cluster 4). Taking into consideration that air advected to KHMS has much often contacts with the lowest tropospheric layers (different to JFJ), the shape of the ozone trends seasonality (slight negative trend in winter and slight positive trend in summer) might possibly also reflect the effect of increased ozone production in the PBL in the source areas (either local or regional).

\subsubsection{Trend analysis of ozone measurements at Jungfraujoch}

In contrast to KHMS ozone mixing ratio has strongly increased at JFJ (see Fig. 8c). Table 7 shows that for the period 1991-2001 the trends at JFJ are positive and statistically significant for all the subsets (including all seasons). The annual trends at JFJ vary in the range from +0.82 to $+0.59 \mathrm{ppb} /$ year. Trends are very close in all FT cases while they are smaller for PBL cases (especially for the air which was in the contact with PBL at least for 2 days of the last 5 before arriving to the station). As far as we do not set a spatial criterion to the area of the sampling in this PBL subset, the PBL may also be sampled over Atlantic.

All trends at JFJ during 1991-2001 (Table 7) are most positive in spring and the least positive in summer and autumn. An exception is the subset with the longest contact with PBL, for which the strongest positive trend is observed 
Table 7. Comparison of trends with $1 \sigma$ standard deviation for different vertical subsets at JFJ for the period 1991-2001 (average monthly frequency is given in the brackets in \%).

\begin{tabular}{lrrrrr}
\hline & annual & DJF & MAM & JJA & SON \\
\hline original data set monthly mean & $0.73 \pm 0.20$ & $0.86 \pm 0.22$ & $0.98 \pm 0.32$ & $0.73 \pm 0.23$ & $0.62 \pm 0.22$ \\
FT cases & & & & & \\
$p<400 \mathrm{hPa}$ & $0.81 \pm 0.20(28.4)$ & $0.93 \pm 0.21(33.3)$ & $1.07 \pm 0.34(24.7)$ & $0.82 \pm 0.26(27.9)$ & $0.68 \pm 0.23(27.8)$ \\
$p<500 \mathrm{hPa} \& \mathrm{PV}>1.3 \mathrm{PVU}$ & $0.80 \pm 0.22(10.9)$ & $0.92 \pm 0.24(13.2)$ & $1.13 \pm 0.37(10.7)$ & $0.63 \pm 0.25(8.6)$ & $0.76 \pm 0.26(11.1)$ \\
$p<500 \mathrm{hPa} \& \mathrm{PV}>1.6 \mathrm{PVU}$ & $0.80 \pm 0.22(8.4)$ & $0.88 \pm 0.23(10.1)$ & $1.08 \pm 0.38(8.6)$ & $0.71 \pm 0.30(6.4)$ & $0.78 \pm 0.25(8.4)$ \\
$p<500 \mathrm{hPa} \& \mathrm{PV}>2$ PVU & $0.82 \pm 0.22(6.5)$ & $0.80 \pm 0.23(7.6)$ & $1.14 \pm 0.37(6.7)$ & $0.72 \pm 0.33(5.3)$ & $0.83 \pm 0.29(6.4)$ \\
PBL cases & & & & & \\
more than 1 contact with PBL east of 10 W & $0.72 \pm 0.21(35.8)$ & $0.78 \pm 0.26(33.7)$ & $0.98 \pm 0.32(41.0)$ & $0.76 \pm 0.24(33.3)$ & $0.66 \pm 0.25(35.3)$ \\
2 of the last 5 days in contact with PBL & $0.59 \pm 0.23(5.9)$ & $0.92 \pm 0.33(7.2)$ & $0.83 \pm 0.33(6.3)$ & $0.35 \pm 0.35(4.3)$ & $0.40 \pm 0.27(5.9)$ \\
\hline
\end{tabular}

Table 8. Comparison of trends with $1 \sigma$ standard deviation for different vertical subsets at JFJ for the period 1997-2006 (average monthly frequency is given in the brackets in \%).

\begin{tabular}{|c|c|c|c|c|c|}
\hline & annual & DJF & MAM & JJA & SON \\
\hline \multicolumn{6}{|l|}{ FT cases } \\
\hline$p<500 \mathrm{hPa} \& \mathrm{PV}>1.3 \mathrm{PVU}$ & $0.03 \pm 0.23(10.1)$ & $0.35 \pm 0.18(12.1)$ & $0.16 \pm 0.31(10.4)$ & $-0.04 \pm 0.24(7.7)$ & $-0.06 \pm 0.29(10.3)$ \\
\hline$p<500 \mathrm{hPa} \& \mathrm{PV}>1.6 \mathrm{PVU}$ & $0.07 \pm 0.23(7.8)$ & $0.44 \pm 0.22(9.5)$ & $0.13 \pm 0.33(8.1)$ & $-0.01 \pm 0.24(5.7)$ & $0.02 \pm 0.28(7.7)$ \\
\hline$p<500 \mathrm{hPa} \& \mathrm{PV}>2 \mathrm{PVU}$ & $0.01 \pm 0.25(6.0)$ & $0.47 \pm 0.23(7.2)$ & $0.12 \pm 0.33(6.4)$ & $-0.33 \pm 0.42(4.3)$ & $0.00 \pm 0.32(6.0)$ \\
\hline \multicolumn{6}{|l|}{ PBL cases } \\
\hline 2 of the last 5 days in contact with PBL & $0.18 \pm 0.26(5.5)$ & $0.32 \pm 0.28(7.2)$ & $0.29 \pm 0.31(6.2)$ & $0.15 \pm 0.38(4.1)$ & $-0.03 \pm 0.39(4.5)$ \\
\hline
\end{tabular}

in winter and the least positive trend is observed in summer. An ozone increase in winter is consistent with the reduction of NO emissions due to air pollutants abatement regulation (less titration of ozone in winter and less production in summer). However, the increase of the surface ozone mixing ratio in the warm season is not explainable with the ozone precursor decrease, which took place during the early 1990s. One may need to take into account that the PBL contact happens over large geographical regions, which are not uniform concerning emissions. PBL contact may occur both over the polluted Northern part of Italy and Spain, with high potential for ozone production in summer and over the large parts of the North Atlantic, which gets somewhat more polluted in the ship track corridor (Dalsøren et al., 2009).

The seasonality of the trends in the FT cases (Table 7) can contain additional information concerning the reasons of the trends: 1) the trends are more positive in the FT/ST group indicating that at the higher levels in the troposphere the growth is more substantial. Ozone growth in the upper troposphere might be connected with increased transport from the stratosphere (see Ordóñez et al., 2007); 2) as far as stratospheric ozone has its seasonal maximum in spring the strongest response on the increased influx is expected for the spring months, which is consistent with our analysis (i.e. the most positive trends in FT subsets are observed in spring). The geographical area, where the stratospheric air is sampled prior to arrival to JFJ (not shown here) suggests that the UTLS regions over North Atlantic/USA East coast and Canada provide the strongest impact on the monthly means in the FT subsets (consistent with Terao et al., 2008).

The trend values are substantially different at JFJ for the later period, i.e. 1997-2006: the annual trends at JFJ (see Table 8, Fig. 9c) are statistically non-significant and close to zero (from +0.18 to $-0.01 \mathrm{ppb} /$ year). The change of the absolute values of the trends is accompanied by the change their seasonality of the trends. They remain mostly positive and statistically significant is winter, different to the other seasons. The least changes of the trends without changes of their seasonality between 1991-2001 and 1997-2006 are observed at JFJ in the subset with the longest contact with the PBL hence the ozone response to the emissions control over Europe seems to be similar in the two periods. The trends in the PBL may be slightly weaker due to the fact that the rate of emission changes has decreased in 1997-2006 in comparison with 1991-2001 (www.emep.int). 
Table 9. Comparison of trends with $1 \sigma$ standard deviation for different horizontal clusters of the air mass advection at JFJ for the period 1991-2001 (average monthly frequency is given in the brackets). Maximal seasonal trends are highlighted by italic.

\begin{tabular}{rrrrrr}
\hline & annual & DJF & MAM & JJA & SON \\
\hline cluster 1 & $1.18 \pm 0.26(3.0)$ & $1.12 \pm 0.29(4.3)$ & $1.88 \pm 0.59(2.5)$ & $0.84 \pm 0.46(2.1)$ & $1.16 \pm 0.36(2.8)$ \\
cluster 2 & $0.75 \pm 0.19(29.7)$ & $0.81 \pm 0.22(29.2)$ & $1.15 \pm 0.36(29.7)$ & $0.73 \pm 0.26(30.7)$ & $0.59 \pm 0.20(29.0)$ \\
cluster 3 & $0.90 \pm 0.27(2.6)$ & $0.85 \pm 0.30(3.6)$ & $2.35 \pm 0.92(2.1)$ & $0.66 \pm 0.46(1.8)$ & $0.69 \pm 0.36(2.4)$ \\
cluster 4 & $0.62 \pm 0.23(18.6)$ & $0.66 \pm 0.25(14.4)$ & $0.82 \pm 0.31(20.3)$ & $0.69 \pm 0.23(20.9)$ & $0.58 \pm 0.32(18.8)$ \\
cluster 5 & $0.52 \pm 0.27(2.2)$ & $0.71 \pm 0.21(2.8)$ & $-0.01 \pm 0.55(1.6)$ & $0.62 \pm 0.57(1.7)$ & $0.73 \pm 0.44(2.1)$ \\
cluster 6 & $0.97 \pm 0.20(16.0)$ & $0.85 \pm 0.22(21.7)$ & $1.37 \pm 0.35(14.4)$ & $1.14 \pm 0.33(12.3)$ & $0.73 \pm 0.24(15.5)$ \\
cluster 7 & $0.65 \pm 0.21(30.3)$ & $0.86 \pm 0.22(25.8)$ & $0.81 \pm 0.32(32.3)$ & $0.63 \pm 0.24(32.7)$ & $0.53 \pm 0.24(30.6)$ \\
\hline
\end{tabular}

Table 10. Comparison of trends with $1 \sigma$ standard deviation for different horizontal clusters of the air mass advection at JFJ for the period 1997-2006 (average monthly frequency is given in the brackets). Statistically significant trends are highlighted by italic.

\begin{tabular}{rrrrrr}
\hline & annual & DJF & MAM & JJA & SON \\
\hline cluster 1 & $-0.06 \pm 0.27(3.2)$ & $0.28 \pm 0.22(5.0)$ & $-0.29 \pm 0.47(2.5)$ & $0.51 \pm 0.65(2.0)$ & $-0.37 \pm 0.29(3.0)$ \\
cluster 2 & $0.03 \pm 0.21(28.7)$ & $0.22 \pm 0.16(28.0)$ & $-0.04 \pm 0.31(28.9)$ & $0.26 \pm 0.27(30.5)$ & $-0.08 \pm 0.25(27.3)$ \\
cluster 3 & $0.23 \pm 0.32(2.4)$ & $0.29 \pm 0.24(3.4)$ & $-0.02 \pm 0.50(1.7)$ & $-0.22 \pm 0.75(1.7)$ & $0.20 \pm 0.48(2.5)$ \\
cluster 4 & $-0.02 \pm 0.25(17.7)$ & $0.31 \pm 0.25(14.6)$ & $0.14 \pm 0.26(19.4)$ & $0.08 \pm 0.23(17.9)$ & $-0.41 \pm 0.41(18.9)$ \\
cluster 5 & $0.01 \pm 0.29(2.1)$ & $-0.25 \pm 0.31(2.7)$ & $0.08 \pm 0.52(1.8)$ & $0.65 \pm 0.58(1.3)$ & $-0.17 \pm 0.36(2.1)$ \\
cluster 6 & $0.03 \pm 0.21(16.3)$ & $0.23 \pm 0.14(22.6)$ & $0.00 \pm 0.28(13.6)$ & $0.18 \pm 0.34(12.6)$ & $-0.13 \pm 0.22(16.5)$ \\
cluster 7 & $0.10 \pm 0.23(31.2)$ & $0.33 \pm 0.18(24.3)$ & $0.18 \pm 0.28(33.7)$ & $0.32 \pm 0.25(35.9)$ & $-0.18 \pm 0.29(30.8)$ \\
\hline
\end{tabular}

The strongest change in the magnitude of the spring trends is observed for the strictest FT subset, which may indicate that contribution from the stratosphere is not increasing anymore and that the average trend is driven by emission regulations mostly. It is unlikely that emissions from Asia can contribute substantially to the surface ozone levels at JFJ as far as they were rising with comparable rate for 1991-2001 and 1997-2006 (van der A et al., 2008), while ozone trend in warm season during the last mentioned period are close to 0 different to the strong positive trends in the earlier years.

The number of FT or PBL cases at JFJ has not changed much (Fig. 9d) and therefore these changes cannot explain the overall average trend. However, the total time spent in the contact with the lowermost stratosphere (PV>2 PVU and pressure less than $500 \mathrm{hPa}$ ) has substantially decreased in 1997-2006 in comparison with 1991-2001 (64038 $\mathrm{h}$ for the earlier period compared to $52146 \mathrm{~h}$ for the later one).

The surface ozone trends at JFJ in the different advection clusters (see Tables 9 and 10) show (similar to the vertical subsets), that ozone trends at JFJ are positive and statistically significant for the period 1991-2001 in all advection clusters (Table 9). The most positive annual trends are observed in the clusters 1, 3 (both observed very rarely) and 6 (observed on average in $16 \%$ of cases), presenting the fastest air advection in the upper troposphere. In general the closer the origin area to Europe is, the smaller are the positive trends.
In most clusters the seasonality of the ozone trends (except for the clusters 5 and 7) is characterized by the strongest positive trend in spring. The most local clusters 4 (Europe) and 7 (Central Atlantic) are characterized by the smallest trends with lower contribution of the air from the upper troposphere over the Atlantic. If the air originates not in the midlatitudes but more in the North (like in cluster 5) in spite of the quite high number of contacts with UTLS $(12.6 \%)$ the ozone trend in spring is close to 0 .

Central Atlantic (cluster 7) trends are rather similar to the ones observed in the local European cluster (cluster 4). In these classes the trends might be viewed as superposition of European emission regulations (more positive in winter, less positive in summer) and the general increase of the ozone levels in the Atlantic troposphere. The role of the emission regulations seems to be less important (taking into account the similarity of the trends in cluster 4 and cluster 7) in comparison with the general level increase over Atlantic, but possibly important enough to modulate the seasonal shape of the trend.

Comparing the trends in the advection clusters for the later period (1997-2006) with the earlier period (1991-2001, see Tables 9 and 10) we found, that the annual trends in all clusters become close to zero. The strongest changes of the trends' values occurred in spring. Proximity of the spring trends to 0 may indicate that the processes, which had provided ozone growth in spring are no longer relevant in the 
second period, i.e. stratospheric contribution in the upper troposphere is not increasing any more. Nevertheless in winter ozone trends in most of clusters remain positive and statistically significant, being the most positive in the cluster 4 (local European) and cluster 7 (Central Atlantic). Assuming that both of these clusters are substantially impacted by European air we can conclude that in winter the small increase of ozone concentration may be associated with European $\mathrm{NO}$ emissions decrease (which is plausible keeping in mind that European $\mathrm{NO}_{\mathrm{x}}$ emission still significantly decreased as shown above). The closeness of the summer trends to 0 may also support this conclusion. Only in the cluster 7 (Central Atlantic) the summer trend is still positive and statistically significant. This is possibly connected with increasing ozone production over Atlantic where ship emissions are rising (Eyring et al., 2007; Dalsøren et al., 2009). Note that summer trend in the cluster, in which air circulates over Europe, is close to zero.

\section{Conclusions}

Ozone variability at two elevated sites situated in the same latitude belt far away from large primary pollutant sources but at different geographical locations (namely the ozone records at Jungfraujoch (Alps) and at Kislovodsk High Mountain station (Caucasus)) was compared. Datasets cover the period from 1990 to 2006 and they belong to the longest continuous surface ozone series. Comparisons of the monthly mean mixing rations showed that ozone levels at two sites were similar in 1990-1993 despite of $1500 \mathrm{~m}$ difference in altitude. At the end of the period (1998-2005) the annual average difference between ozone levels at two sites was around $15 \mathrm{ppb}$.

Both sites are characterized by a wide spring-summer seasonal maximum. Analysis of the 3-D trajectories for the whole measurement period showed that for the subsets more impacted by the stratosphere (with PV exceeding $2 \mathrm{PVU}$ along the trajectory) the spring maximum is dominating, while summer maximum is more controlled by ozone production in the PBL (selected as the cases when trajectory spent more than 2 days of the last five before arrival at the site in the contact with the PBL). Analysis of the seasonal cycle for the different horizontal advection clusters showed that spring maximum prevails at both JFJ and KHMS in the clusters associated with the long-range transport and originating in the free troposphere above East Asia, while overall contribution of this transport way is relatively small. In the clusters of the local/regional advection summer maximum is prevailing also at both locations showing the importance of the ozone photochemical production in the polluted air masses which were in the contact with European PBL.

The trends of surface ozone at JFJ and KHMS were studied for two different periods: in 1991-2001 strong concentration changes occurred at both stations whereas in 1997-
2006 ozone concentrations stabilized. For the earlier period (1991-2001) trends are substantially negative at KHMS and positive at JFJ. Trends at JFJ are the most positive in spring and the least positive in summer and autumn. In contrary the trends in the 1990s at KHMS are the most negative in summer and the least negative in winter and autumn. For the period 1997-2006 the trends at JFJ are close to zero on average and for most of seasons, except for winter when they are still positive and statistically significant. At KHMS the trends remained negative on average and for the most of seasons, except for summer. Seasonality of the trends at KHMS for 1997-2006 is opposite to the one in the earlier period.

One main reason of the differences in ozone trends at KHMS and JFJ is most likely the difference in the position of the stations relative to the source areas affecting ozone variations in the Caucasus and the Alps. The position of KHMS close to the Caucasus Ridge and far from the border of the continent makes this location more sensitive to the wider range of factors, controlling ozone in the continental planetary boundary layer. Both substantial emission decreases in the 1990s due to break down of the former USSR and measures in Europe to control emissions are most likely reasons for the decrease of ozone at KHMS (effects of changes in dynamical processes were not found in the used trajectory analysis but their potential role needs further studies). Being higher in altitude and closer to Atlantic ocean JFJ is more sensitive to the background ozone changes in the free troposphere over the ocean, while emission changes also might contribute to the trends such as increase in the shipping emission in Atlantic.

These findings are supported by the analyzes of different subsets concerning summer ozone trends at KHMS in the 1991-2001 which point to strong emission reductions in the regions surrounding station (from local to European scale) both in PBL cases and air advection clusters. However, winter trends at KHMS are hardly explicable only based on emission trends as far as no firm data concerning NO-emission changes in the area seem available today. Moreover the role of dynamical factors in the trends negative bias also remains unclear.

We found some new evidence, that the positive trends of surface ozone at JFJ in the 1991-2001 are connected with an increased contribution from the stratosphere over Atlantic by the analysis of the free tropospheric/stratospheric subsets (where the highest positive trends were found in the longest and the highest traveling horizontal clusters) and by the seasonality of the trends (maximum positive trends are observed in spring). The response to the regional European emissions decrease seems to be less important. During the later years (1997-2006) ozone trends at JFJ became close to zero. 
Acknowledgements. The project is supported by the Swiss National Science Foundation (JRP IB7320-110831), the European Commission (Marie-Curie IIF project N 039905 - FP6-2005-Mobility-7) the Russian Foundation for Basic Research (project 06-05-64427 and 06-05-65308) and a research grant of Swiss Federal Institute of Technology, Zurich. The Swiss Federal Laboratories for Materials Testing and Research (Empa) and The Swiss Federal Office for the Environment (FOEN) are acknowledged for providing $\mathrm{O}_{3}$ data at Jungfraujoch.

\section{Edited by: P. Monks}

The service charges for this open access publication have been covered by the Max Planck Society.

\section{References}

Andreani-Aksoyoglu, S., Keller, J., Ordóñez, C., Tinguely, M., Schultz, M., and Prevot, A. S. H.: Influence of various emission scenarios on ozone in Europe, Ecol. Modell., 217, 209-218, 2008.

Auvray, M. and Bey, I.: Long-range transport to Europe: Seasonal variations and implications for the European ozone budget, J. Geophys. Res., 110, D11303, doi:10.1029/2004JD005503, 2005.

Baltensperger, U., Gäggeler, H., Jost, D., Lugauer, M., Schwikowski, M., Weingartner, E., and Seibert, P.: Aerosol climatology at the high-alpine site Jungfraujoch, Switzerland, J. Geophys. Res., 102(D16), 19707-19715, 1997.

Brönnimann, S., Buchmann, B., and Wanner, H.: Trends in nearsurface ozone concentrations in Switzerland: the 1990s, Atmos. Environ., 36(17), 2841-2852, 2002.

Brönnimann, S., Schuepbach, E., Zanis, P., Buchmann, B., Wanner, H.: A climatology of regional background ozone at different elevations in Switzerland (1992-1998), Atmos. Environ., 34(2930), 5191-5198, 2000.

Campana, M., Li, Y., Staehelin, J., Prevot, A. S. H., Bonasoni, P., Loetscher, H., and Peter, T.: The influence of south foehn on the ozone mixing ratios at the high alpine site Arosa, Atmos. Environ., 39(16), 2945-2955, 2005.

Cape, J. N., Methven, J., and Hudson, L. E.: The use of trajectory cluster analysis to interpret trace gas measurements at Mace Head, Ireland, Atmos. Environ., 34(22), 3651-3663, 2000.

Chevalier, A., Gheusi, F., Delmas, R., Ordóñez, C., Sarrat, C., Zbinden, R., Thouret, V., Athier, G., and Cousin, J.-M.: Influence of altitude on ozone levels and variability in the lower troposphere: a ground-based study for western Europe over the period 2001-2004, Atmos. Chem. Phys., 7, 4311-4326, 2007, http://www.atmos-chem-phys.net/7/4311/2007/.

Cristofanelli, P. , Bonasoni, P. Carboni, G. , Calzolari, F., Casarola, L., Zauli Sajani, S., and Santaguida, R.: Anomalous high ozone concentrations recorded at a high mountain station in Italy in summer 2003, Atmos. Environ., 41, 1383-1394, 2007.

Dalsøren, S. B., Eide, M. S., Endresen, Ø., Mjelde, A., Gravir, G., and Isaksen, I. S. A.: Update on emissions and environmental impacts from the international fleet of ships: the contribution from major ship types and ports, Atmos. Chem. Phys., 9, 2171-2194, 2009 ,

http://www.atmos-chem-phys.net/9/2171/2009/.
Derwent, R. G., Simmonds, P. G., Manning, A. J., and Spain, T. G.: Trends over a 20-year period from 1987-2007 in surface ozone at the atmospheric research station, Mace Head, Ireland, Atmos. Environ., 41, 9091-9098, 2007.

EMEP: Assessment Part I, European Perspective, EMEP, Oslo, 2004.

EMPA: EMPA (Swiss Federal Laboratories for Materials Testing and Research), 2000, Technischer Bericht zum Nationalen Beobachtungsnetz für Luftfremdstoffe (NABEL) 2000, Dübendorf, 2000.

Eyring, V., Stevenson, D. S., Lauer, A., Dentener, F. J., Butler, T., Collins, W. J., Ellingsen, K., Gauss, M., Hauglustaine, D. A., Isaksen, I. S. A., Lawrence, M. G., Richter, A., Rodriguez, J. M., Sanderson, M., Strahan, S. E., Sudo, K., Szopa, S., van Noije, T. P. C., and Wild, O.: Multi-model simulations of the impact of international shipping on Atmospheric Chemistry and Climate in 2000 and 2030, Atmos. Chem. Phys., 7, 757-780, 2007, http://www.atmos-chem-phys.net/7/757/2007/.

Götz, F. W. P and Volz, T.: Aroser Messungen des Ozongehaltes in der unteren Troposphäre und sein Jahresgang, Z. Naturforsch., 6a, 634-639, 1951.

Helmig, D., Oltmans, S. J., Carlson, D., Lamarque, J.-F., Jones, A., Labuschagne, C., Anlauf, K., and Hayden, K.: A review of surface ozone in the polar regions, Atmos. Environ., 41(24), 51385161, 2007.

Henne, S., Furger, M., and Prevot, A. S. H.: Climatology of mountain venting-induced elevated moisture layers in the lee of the Alps, J. Appl. Meteorol., 44, 620-633, 2005.

Henne, S., Furger, M., Nyeki, S., Steinbacher, M., Neininger, B., de Wekker, S. F. J., Dommen, J., Spichtinger, N., Stohl, A., and Prév^t, A. S. H.: Quantification of topographic venting of boundary layer air to the free troposphere, Atmos. Chem. Phys., 4, 497509, 2004,

http://www.atmos-chem-phys.net/4/497/2004/.

Information of the Goskomstat of Russia: Financial- Economical Bulletin of Oil and Gas Industry, N 4, 1999.

IPCC, 2007: Climate Change 2007: Synthesis Report. Contribution of Working Groups I, II and III to the Fourth Assessment Report of the Intergovernmental Panel on Climate Change, edited by: Core Writing Team, Pachauri, R. K and Reisinger, A., IPCC, Geneva, Switzerland, 104 pp, 2007.

Jaffe, D. and Ray, J.: Increase in surface ozone at rural sites in the western US, Atmos. Environ., 41(26), 5452-5463, 2007

Jonson, J. E., Simpson, D., Fagerli, H., and Solberg, S.: Can we explain the trends in European ozone levels?, Atmos. Chem. Phys., 6, 51-66, 2006, http://www.atmos-chem-phys.net/6/51/2006/.

Klausen, J., Zellweger, C., Buchmann, B., and Hofer, P.: Uncertainty and bias of surface ozone measurements at selected Global Atmospheric Watch sites, J. Geophys. Res, 108(D19), 4622, doi:10.1029/2003JD003710, 2003.

Koumoutsaris, S., Bey, I. , Generoso,V., and Thouret, V.: Influence of El Ninõ-Southern Oscillation on the interannual variability of tropospheric ozone in the northern midlatitudes, J. Geophys. Res., 113, D19301, doi:10.1029/2007JD009753, 2008.

Lee, H. N., Tositti, L., Zheng, X., and Bonasoni, P.: Analyses and comparisons of variations of ${ }^{7} \mathrm{Be},{ }^{210} \mathrm{~Pb}$, and ${ }^{7} \mathrm{Be} /{ }^{210} \mathrm{~Pb}$ with ozone observations at two Global Atmosphere Watch stations from high mountains, J. Geophys. Res., 112, D05303, 
doi:10.1029/2006JD007421, 2007.

Linvill, D. E., Hooker, W. J., and Olson, B.: Ozone in Michigan's Environment 1876-1880, Mon. Weather Rev., 108, 1883-1891, 1980.

Liu, J. J., Jones, D. B. A., Worden, J. R., Noone, D., Parrington, M., and Kar, J.: Analysis of the summertime buildup of tropospheric ozone abundances over the Middle East and North Africa as observed by the Tropospheric Emission Spectrometer instrument, J. Geophys. Res., 114, D05304, doi:10.1029/2008JD010993, 2009.

Logan, J. A.: Tropospheric Ozone: Seasonal Behavior, Trends, and Anthropogenic Influence, J. Geophys. Res., 90(D6), 1046310482, 1985.

Monks, P. S.: A review of the observations and origins of the spring ozone maximum, Atmos. Environ., 34(21), 3545-3561, 2000.

Nolle, M., Ellul, R., Ventura, F., and Güsten, H.: A study of historical surface ozone measurements (1884-1900) on the island of Gozo in the central Mediterranean, Atmos. Environ., 39(30), 5608-5618, 2005.

Oltmans, S. J., Lefohn, A. S., Harris, J. M., Galbally, I. , Scheel, H. E., Bodeker, G., Brunke, E., Claude, H., Tarasick, D., Johnson, B. J., Simmonds, P., Shadwick, D., Anlauf, K., Hayden, K., Schmidlin, F., Fujimoto, T., Akagi, K., Meyer, C., Nichol, S., Davies, J., Redondas, A., and Cuevas, E.: Long-term changes in tropospheric ozone, Atmos. Environ., 40, 3156-3173, 2006.

Ordóñez, C., Brunner, D., Staehelin, J., Hadjinicolaou, P., Pyle, J. A., Jonas, M., Wernli, H., and Prevot, A. S. H.: Strong influence of lowermost stratospheric ozone on lower tropospheric background ozone changes over Europe, Geophys. Res. Lett., 34(7), L07805, doi 10.1029/2006GL029113, 2007.

Ordóñez, C., Mathis, H., Furger, M., Henne, S., Hüglin, C., Staehelin, J., and Prév^t, A. S. H.: Changes of daily surface ozone maxima in Switzerland in all seasons from 1992 to 2002 and discussion of summer 2003, Atmos. Chem. Phys., 5, 1187-1203, 2005 ,

http://www.atmos-chem-phys.net/5/1187/2005/.

Parrish, D. D., Millet, D. B., and Goldstein, A. H.: Increasing ozone in marine boundary layer inflow at the west coasts of North America and Europe, Atmos. Chem. Phys., 9, 1303-1323, 2009, http://www.atmos-chem-phys.net/9/1303/2009/.

Scheel, H. E.: Ozone Climatology Studies for the Zugspitze and Neighbouring Sites in the German Alps, TOR-2 Final Report, 134-139, 2003.

Schuepbach, E., Friedli, T. K., Zanis, P., Monks, P. S., and Penkett, S. A.: State space analysis of changing seasonal ozone cycles (1988-1997) at Jungfraujoch (3580 m above sea level) in Switzerland, J. Geophys. Res., 106(D17), 20413-20427, 2001.

Senik, I. A. and Elansky, N. F.: Surface Ozone Concentration Measurements at the Kislovodsk High-Altitude Scientific Station: Temporal Variations and Trends, Izvestiya, Atmos. Ocean. Phys., 37, Suppl. 1, S110-S119, 2001.

Senik, I. A., Elansky, N. F., Belikov, I. B., Lisitsyna, L. V., Galaktionov, V. V., and Kortunova, Z. V.: Main Patterns of the Temporal Variability of Surface Ozone in the Vicinity of the Town of Kislovodsk at 870 and $2070 \mathrm{~m}$ above Sea Level, Izvestiya, Atmos. Ocean. Phys., 41, Suppl. 1, 67-79, 2005.

Simmonds, P. G., Derwent, R. G., Manning, A. L., and Spain, G.: Significant growth in surface ozone at Mace Head, Ireland, 1987-2003, Atmos. Environ., 38(28), 4769-4778, 2004.

Staehelin, J., Harris, N. R. P., Appenzeller, C., and Eberhard, J.:
Ozone trends: A review, Rev. Geophys., 39, 231-290, 2001.

Staehelin, J., Thudium, J., Bühler, R., Volz, A., and Graber, W.: Surface ozone trends at Arosa (Switzerland), Atmos. Environ., 28, 75-87, 1994.

Stevenson, D. S., Dentener, F. J., Schultz, M. G., et al.: Multimodel ensemble simulations of present-day and near future tropospheric ozone, J. Geophys. Res., 111, D08301, doi:10.1029/2005JD006338, 2006.

Tarasova, O. A., Brenninkmeijer, C. A. M., Jöckel, P., Zvyagintsev, A. M., and Kuznetsov, G. I.: A climatology of surface ozone in the extra tropics: cluster analysis of observations and model results, Atmos. Chem. Phys., 7, 6099-6117, 2007, http://www.atmos-chem-phys.net/7/6099/2007/.

Tarasova, O. A., Elansky, N. F., Kuznetsov, G. I., Kuznetsova, I. N., and Senik, I. A.: Impact of air transport on seasonal variations and trends of surface ozone at Kislovodsk High Mountain Station, J. Atmos. Chem., 45, 245-259, 2003.

Terao, Y., Logan, J. A., Douglass, A. R., and Stolarski, R. S.: Contribution of stratospheric ozone to the interannual variability of tropospheric ozone in the northern extratropics, J. Geophys. Res, 113, D18309, doi:10.1029/2008JD009854, 2008.

Thouret, V., Cammas, J.-P., Sauvage, B., Athier, G., Zbinden, R., Nédélec, P., Simon, P., and Karcher, F.: Tropopause referenced ozone climatology and inter-annual variability (1994-2003) from the MOZAIC programme, Atmos. Chem. Phys., 6, 1033-1051, 2006 ,

http://www.atmos-chem-phys.net/6/1033/2006/.

Tropospheric Ozone Research (TOR-2): in Towards Cleaner Air for Europe - Science, Tools and Applications, Part 2. Overviews from the Final Reports of the EUROTRAC-2 Subprojects, edited by: Midgley, P. M. and Reuther, M., Margraf Verlag, Weikersheim, 2003.

van $\operatorname{der}$ A, R. J., Eskes, H. J., Boersma, K. F., van Noije, T. P. C., van Roozendael, M., De Smedt, I., Peters, D. H. M. U., and Meijer, E. W.: Trends, seasonal variability and dominant $\mathrm{NO}_{\mathrm{x}}$ source derived from a ten year record of $\mathrm{NO}_{2}$ measured from space, $\mathrm{J}$. Geophys. Res., 113, D04302, doi:10.1029/2007JD009021, 2008.

Vingarzan, R.: A review of surface ozone background levels and trends, Atmos. Environ., 38, 3431-3442, 2004.

Wang, T., Wong, H. L. A., Tang, J., Ding, A., Wu, W. S., and Zhang, X. C.: On the origin of surface ozone and reactive nitrogen observed at a remote mountain site in the northeastern QinghaiTibetan Plateau, western China, J. Geophys. Res., 111, D08303, doi:10.1029/2005JD006527, 2006.

Wernli, H. and Davies, H.: A Lagrangian-based analysis of extratropical cyclones, 1, The method and some applications, Q. J Roy. Meteorol. Soc., 123, 467-489, 1997.

Zanis, P. , Schuepbach, E., Scheel, H. E., Baudenbacher, M., and Buchmann, B.: Inhomogeneities and trends in the surface ozone record (1988-1996) at Jungfraujoch in the Swiss Alps, Atmos. Environ., 33(23), 3777-3786, 1999.

Zanis, P., Ganser, A., Zellweger, C., Henne, S., Steinbacher, M., and Staehelin, J.: Seasonal variability of measured ozone production efficiencies in the lower free troposphere of Central Europe, Atmos. Chem. Phys., 7, 223-236, 2007, http://www.atmos-chem-phys.net/7/223/2007/.

Zbinden, R. M., Cammas, J.-P., Thouret, V., Nédélec, P., Karcher, F., and Simon, P.: Mid-latitude tropospheric ozone columns from the MOZAIC program: climatology and interannual variability, 
Atmos. Chem. Phys., 6, 1053-1073, 2006,

http://www.atmos-chem-phys.net/6/1053/2006/.

Zellweger, C., Forrer, J., Hofer, P., Nyeki, S., Schwarzenbach, B., Weingartner, E., Ammann, M., and Baltensperger, U.:
Partitioning of reactive nitrogen $\left(\mathrm{NO}_{\mathrm{y}}\right)$ and dependence on meteorological conditions in the lower free troposphere, Atmos. Chem. Phys., 3, 779-796, 2003,

http://www.atmos-chem-phys.net/3/779/2003/. 